\title{
Prospek Utama Pengembangan Energi Terbarukan Di Negara-Negara ASEAN
}

\author{
Syaifuddin Yana ${ }^{1 *}$, Muhammad Nizar ${ }^{2}$, Ardhana Yulisma $^{3}$ \\ ${ }^{1}$ Program Studi Teknik Industri, Fakultas Teknik Universitas, Serambi Mekkah \\ ${ }^{2}$ Program Studi Teknik, Lingkungan, Fakultas Teknik Universitas Serambi Mekkah \\ ${ }^{3}$ Program Studi Magister Biologi, Fakultas Matematika dan Ilmu Pengetahuan Alam, Universitas Syiah Kuala \\ *Koresponden email: syaifuddin.yana@serambimekkah.ac.id
}

Diterima: 11 Februari 2021

Disetujui: 22 Februari 2021

\begin{abstract}
The economic development of a country depends on sustainable energy sources that meet basic human needs. Government policy on energy conservation is an effort to maintain the stability of energy security that affects the economic development of a country. Southeast Asia is experiencing rapid economic growth and development, combined with population growth and urbanization, as well as increased access to basic services. This study aimed to determine the seven key factors considered that shape energy in Southeast Asia. Based on the panel data model, it showed that energy demand in the ASEAN region greatly influences GDP per capita; demographics and urbanization; air quality, climate risk, and environmental degradation; energy accessibility, affordability, and security; investment and financial ; as well as energy policies, prices, and regulations.
\end{abstract}

Keywords: seven key factors, renewable energy, energy development, energy security, ASEAN

\section{Abstrak}

Perkembangan ekonomi suatu negara tergantung pada pasokan energi berkelanjutan yang mampu memenuhi seluruh kebutuhan dasar masyarakat. Kebijakan pemerintah dalam konservasi energi merupakan upaya menjaga stabilitas keamanan energi yang berpengaruh terhadap pembangunan ekonomi di suatu Negara. Asia Tenggara mengalami pertumbuhan dan perkembangan ekonomi yang cukup pesat, hal tersebut dikombinasikan dengan meningkatnya populasi dan urbanisasi, serta peningkatan akses ke layanan dasar. Penelitian ini bertujuan untuk mengetahui tujuh faktor kunci yang membentuk energi di kawasan Asia Tenggara. Berdasarkan model data panel menunjukkan bahwa permintaan energi di kawasan ASEAN sangat berpengaruh terhadap PDB per kapita; demografi dan urbanisasi; kualitas udara, risiko iklim, dan degradasi lingkungan; akses, keterjangkauan, dan keamanan energi; investasi dan pembiayaan; serta kebijakan energi, harga, dan regulasi.

Kata Kunci : tujuh faktor kunci, energi terbarukan, pengembangan energi, keamanan energi, ASEAN

\section{Pendahuluan}

Penduduk ASEAN berjumlah lebih dari 500 juta orang yang tersebar di 10 negara dengan luas wilayah sekitar 4,5 juta $\mathrm{km}^{2}$. Pada Tahun 1990-an terjadi peningkatan pertumbuhan Asia meliputi industrialisasi secara besar, peningkatan migrasi perkotaan ke daerah-daerah populasi yang sangat terkonsentrasi, kelas menengah yang berkembang, dan pendapatan konsumen yang semakin meningkat. Sementara itu, pada Tahun 2001 terjadi perlambatan ekonomi global menghambat permintaan energi dan ekonomi kawasan hal ini dipicu oleh krisis ekonomi Asia pada Tahun 1997 [1]. Asia Tenggara merupakan wilayah yang dinamis dan beragam dalam banyak hal. Hal ini ditandai dengan pertumbuhan demografis dan ekonomi yang signifikan. Juga, oleh berbagai tingkat pembangunan dan sumber daya alam yang tidak merata. Negara-negara berkembang seperti Asia Tenggara mengkonsumsi energi dalam jumlah yang banyak, terutama dalam penggunaan listrik. Sejak Tahun 2000 batu bara menempati posisi terdepan dalam memenuhi tuntutan baru ini, dengan mengorbankan lingkungan [2].

Energi merupakan hal terpenting dalam memenuhi kebutuhan dasar manusia, serta menjadi fundamental dalam mendukung kegiatan industri, transportasi, dan pertanian yang membentuk pertumbuhan ekonomi dunia [3]. Perkembangan ekonomi suatu negara tergantung pada pasokan energi berkelanjutan yang memenuhi semua kebutuhan yang diperlukan. Konservasi energi dan kebijakan pemerintah yang ditetapkan untuk mendukung keamanan energi memainkan peran utama dalam mempertahankan pembangunan ekonomi suatu negara. Setiap penilaian prospek energi global harus 
memperhitungkan pertumbuhan ekonomi di Asia Tenggara. Kawasan Asia Tenggara merupakan rumah bagi hampir satu dari sepuluh populasi dunia, dimana pertumbuhan ekonomi di kawasan ini secara cepat membentuk banyak aspek dari prospek ekonomi dan energi global. Meningkatnya permintaan bahan bakar, terutama untuk minyak, telah jauh melampaui produksi dari dalam kawasan. Asia Tenggara secara keseluruhan sekarang berada di ambang menjadi importir bersih bahan bakar fosil untuk pertama kalinya. Pada saat yang sama, Asia Tenggara sedang menuju untuk mencapai akses ke listrik secara universal pada Tahun 2030 [4]. Dalam Skenario Pembangunan Berkelanjutan, pangsa energi terbarukan dalam pembangkit listrik hampir tiga kali lipat dari level saat ini pada Tahun 2040, yaitu mencapai $70 \%$. Di dalam dan di luar sektor listrik, Asia Tenggara memiliki potensi besar untuk penggunaan berkelanjutan bioenergi modern, baik dalam hal teknologi saat ini dan dalam pengembangan biofuel maju untuk meningkatkan keberlanjutan sektor transportasi [4].

Menurut Ref. [4], jumlah konsumsi energi di wilayah ASEAN secara praktis akan berlipat ganda pada Tahun 2040. Oleh karena itu, energi konvensional masih dapat digunakan oleh sebagian besar negara-negara ASEAN untuk memenuhi permintaan energi yang terus meningkat, dengan upaya untuk mengurangi dampak lingkungan, dan secara bertahap meningkatkan penggunaan energi terbarukan [5]. Pasar energi di Asia Tenggara berkembang pesat. Permintaan keseluruhan telah meningkat $80 \%$ sejak Tahun 2000, dengan jutaan pelanggan baru mendapatkan akses ke listrik. Hal tersebut memberi tekanan pada sistem energi, dan dengan banyak permintaan dipenuhi oleh dua kali lipat penggunaan bahan bakar fosil, emisi $\mathrm{CO}_{2}$ juga meningkat [6].

Wilayah Asia Tenggara memiliki sumber daya energi terbarukan yang kaya dan sebagian besar belum dimanfaatkan. Ini memiliki beberapa potensi tenaga air terbaik di dunia, terutama di Indonesia, Myanmar dan beberapa negara Mekong. Iradiasi horizontal global merupakan parameter yang dipertimbangkan untuk instalasi fotovoltaik di wilayah tersebut, dengan rata-rata tahunan 1,5-2 $\mathrm{MWh} /$ $\mathrm{m} 2$ per tahun. Sumber daya angin lebih banyak pada wilayah Indonesia, Filipina, Thailand, dan Vietnam mencapai kecepatan rata-rata antara enam dan tujuh meter per detik. Indonesia dan Filipina memiliki pengaruh yang signifikan potensi panas bumi [7]. Dalam hal "cadangan terbukti" sumber daya yang dapat dieksploitasi secara ekonomi dengan teknologi. Saat ini Indonesia memimpin wilayah dan bertanggung jawab dalam peningkatan kapasitas substansial di masa depan. Meskipun tidak cukup dipetakan, kawasan ini juga memiliki potensi energi laut yang besar, terutama di negara-negara kepulauan seperti Indonesia, Filipina, dan Singapura [8]. Potensi pasokan bioenergi signifikan di seluruh wilayah dengan berbagai pilihan bahan baku yang tersedia, termasuk residu pertanian, limbah ternak, dan hutan perkebunan.

Pembuat kebijakan memerlukan data untuk menginformasikan perencanaan nasional, penetapan target, dan desain kebijakan sektor untuk mengembangkan proposal proyek, mengidentifikasi potensi lokasi dan melakukan studi kelayakan awal, dan investor untuk menilai proposal dan risiko keuangan dalam pengembangan sumber daya energi terbarukan [9]. Keamanan energi adalah konsep yang bergantung pada konteks [9][10][11]. Keamanan energi dapat didefinisikan sebagai pasokan atau permintaan energi yang andal dan memadai dengan harga terjangkau [12][13]. Menurut Ref. [14] keamanan energi merupakan kemampuan rumah tangga, bisnis, dan pemerintah untuk mengakomodasi gangguan pasokan di pasar energi. Beberapa literatur menekankan ketersediaan dan keterjangkauan energi, seperti akses ke sumber energi yang cukup, termasuk infrastruktur untuk transportasi energi [15]. Definisi keamanan energi juga bergantung pada apakah negara tersebut adalah eksportir energi atau importir energi [12][16][17]. Penelitian ini bertujuan untuk mengetahui tujuh faktor kunci yang membentuk prospek energi dalam pengembangan energi terbarukan di kawasan Asean.

\section{Metode Penelitian}

Penelitian ini merupakan penelitian kualitatif yang bersifat study literature yang menggunakan buku-buku dan literatur-literatur terkini. Jenis penelitian yang digunakan adalah kualitatif, yaitu penelitian yang menghasilkan informasi berupa catatan dan data deskriptif yang terdapat di dalam teks yang diteliti. Tabulasi sumber data yang digunakan dalam studi ini dapat dilihat pada Tabel 1. 
Tabel 1. Sumber data yang digunakan dalam study literature

\begin{tabular}{|c|c|c|c|}
\hline Literatur & $\begin{array}{l}\text { Tahun Terbit } \\
\text { Literatur }\end{array}$ & $\begin{array}{l}\text { Asal Negara } \\
\text { Literatur }\end{array}$ & Sumber \\
\hline $\begin{array}{l}\text { ASEAN UP. } 4 \text { ASEAN infographics: } \\
\text { demography, top cities, urbanization. } \\
\text { Diakses pada Tanggal } 17 \text { Februari } \\
2020 \text { di https://aseanup.com/asean- } \\
\text { infographics-demography-top-cities- } \\
\text { urbanization/ }\end{array}$ & 2020 & - & ASEAN UP \\
\hline $\begin{array}{l}\text { https://www.imf.org/en/Publications/ } \\
\text { WEO/Issues/2020/06/24/WEOUpdateJ } \\
\text { une2020 }\end{array}$ & 2020 & & $\begin{array}{l}\text { International Monetary Fund, World } \\
\text { Economic Outlook. }\end{array}$ \\
\hline $\begin{array}{l}\text { The Asean Post, 2019, ASEAN growth } \\
\text { slower than forecasted, Diakses } \\
\text { Tanggal } 16 \text { Februari } 2021 \text { pada } \\
\text { https://theaseanpost.com/article/asean- } \\
\text { growth-slower-forecasted }\end{array}$ & 2019 & Indonesia & The Asean Post \\
\hline $\begin{array}{l}\text { https://asean.org/storage/2019/06/AEI } \\
\text { B_5th_Issue_Released.pdf } \\
\text { http://www.aseanstats.org/ (data } \\
\text { primer) }\end{array}$ & 2019 & Indonesia & $\begin{array}{l}\text { Asean Economic Integration Brief } \\
\text { No. } 5 \text {. }\end{array}$ \\
\hline $\begin{array}{l}\text { Economic Outlook For Southeast Asia, } \\
\text { China And India } 2019 \\
\text { Towards Smart Urban Transportation, }\end{array}$ & 2019 & Indonesia & $\begin{array}{l}\text { OECD } \text { Development } \text { Centre, MPF- } \\
2019 \text { (Medium-term Projection } \\
\text { Framework) }\end{array}$ \\
\hline $\begin{array}{l}\text { https://www.aseantoday.com/2019/11/t } \\
\text { he-power-of-people-urbanisation-will- } \\
\text { radically-transform-asean-cities-by- } \\
\text { 2050/ }\end{array}$ & 2019 & - & www.worldometers.info \\
\hline https://eneken.ieej.or.jp/data/7748.pdf & 2018 & - & IEEJ: Asia/World Energy Outlook \\
\hline $\begin{array}{l}\text { https://www.irena.org/- } \\
\text { /media/Files/IRENA/Agency/Publicati } \\
\text { on/2018/Jan/IRENA_Market_Southeas } \\
\text { t_Asia_2018.pdf }\end{array}$ & 2018 & ASEAN & $\begin{array}{l}\text { IRENA, Renewable Energy Market } \\
\text { Analysis Southeast Asia. }\end{array}$ \\
\hline $\begin{array}{l}\text { Kreft, Sönke, D. Eckstein, I. Melchior, } \\
\text { "Global Climate Risk Index 2017: } \\
\text { Who Suffers Most from Extreme } \\
\text { Weather Events? Weather-related Loss } \\
\text { Events in } 2015 \text { and } 1996 \text { to } 2015\end{array}$ & 2016 & Germany & $\begin{array}{l}\text { https:// } \\
\text { germanwatch.org/de/download/16411 } \\
\text {.pdf }\end{array}$ \\
\hline $\begin{array}{l}\text { http://aperc.ieej.or.jp/publications/repo } \\
\text { rts/outlook.php }\end{array}$ & 2013 & Tokyo & $\begin{array}{l}\text { APERC, APEC Energy Demand and } \\
\text { Supply Outlook, 5th Edition, Asia } \\
\text { Pacific Energy Research Centre, } \\
\text { Tokyo. }\end{array}$ \\
\hline $\begin{array}{l}\text { P. Ruangrong, "Overview of recent } \\
\text { regulatory developments", presentation } \\
\text { to the High-Level Meeting of Regional } \\
\text { Energy Regulatory Associations of } \\
\text { Emerging Markets. }\end{array}$ & 2013 & Thailand & $\begin{array}{l}\text { http://www.erranet.org/OtherActivitie } \\
\text { s/high-level_meetings }\end{array}$ \\
\hline
\end{tabular}

\section{Hasil dan Pembahasan}

\section{Tren Ekonomi dan Pendapatan yang Meningkat}

Data dari Bank Pembangunan Asia (ADB) terbaru menunjukkan bahwa ekonomi Asia Tenggara telah tumbuh kurang dari yang diperkirakan, dimana menghasilkan pertumbuhan dengan perincian, yaitu 4,8\% (2019) dan 4,9 persen (2020), turun sekitar 4,9\% dan 5,0\% untuk masing-masingnya. Sementara itu, inflasi regional untuk Tahun 2019 diperkirakan turun menjadi 2,4\% dari perkiraan sebelumnya 2,6\%. Terjadinya persaingan dagang di Amerika Serikat (AS) juga berdampak pada pertumbuhan ekonomi di kawasan ASEAN. Hal ini terlihat dari penurunan yang terjadi dalam siklus elektronik, meskipun sebagiannya masih mampu untuk diimbangi oleh permintaan domestik [18]. Pertumbuhan Produk Domestik Bruto (GDP) negara-negara ASEAN tahun 2019 dapat dilihat pada Gambar 1. 


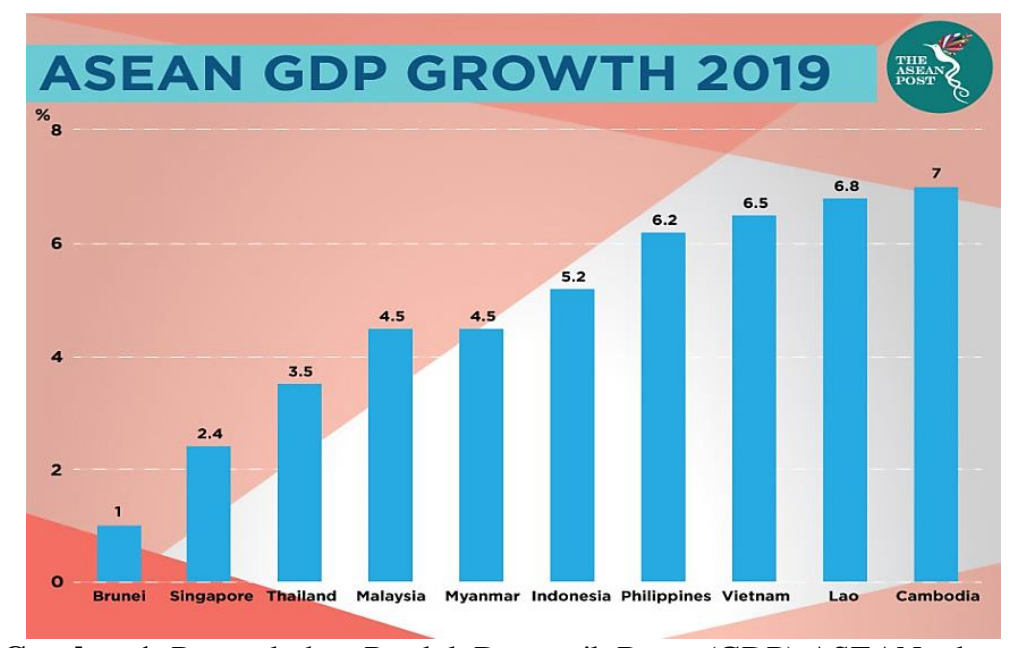

Gambar 1. Pertumbuhan Produk Domestik Bruto (GDP) ASEAN tahun 2019 Sumber: Asian Development Bank, 2019

Gambar 1 menunjukkan bahwa pertumbuhan Produk Domestik Bruto (GDP) terbaik di ASEAN ditempati oleh Kamboja denga pertumbuhan $8 \%$, diikuti oleh Laos (6,8\%), Vietnam (6,5\%), Piliphina $(6,2 \%)$, Indonesia (5,2\%), Thailand (3,5\%), Singapura (2,4\%), dan Brunei (1\%). Sementara Malaysia dan Myanmar mengalami pertumbuhan GDP yang setara yaitu 4,5\%. Ketika konflik perdagangan terus berlanjut, kawasan ini tetap mempertahankan pertumbuhan yang kuat dan moderat. Namun demikian, selama masih terjadi ketegangan antara Amerika Serikat (AS) dan Cina ketidakpastian akan terus membebani prospek secara regional.

PDB di negara berkembang pertumbuhan rata-rata tahunannya yaitu 6,1\% pada 2019. Hal ini berdasarkan pada Kerangka Kerja Jangka Menengah OECD Development Centre (MPF-2019) Pusat Pengembangan (MPF-2019) (Tabel 2). Permintaan domestik diperkirakan akan mempertahankan momentumnya, khususnya rumah tangga pengeluaran, karena pasar dagang diperkirakan akan tetap cerah. Pasar dagang Asia Tenggara diperkirakan akan terus tumbuh sebesar 5,2\% pada 2019, lebih cepat dari tingkat yang dilaporkan pada 2012. Sementara Cina diperkirakan akan memiliki pertumbuhan ratarata $5,9 \%$ pada 2019 , lebih lambat dari rata-rata 2012, yaitu sebesar 7,3\% [19].

Tabel 2. Pertumbuhan PDB di Asia Tenggara dan Cina

\begin{tabular}{lccccc}
\hline & 2017 & 2018 & 2019 & 2019 (rata-rata) & 2012 (rata-rata) \\
\hline Negara ASEAN & & & & & \\
\hline Indonesia & 5.1 & 5.2 & 5.2 & 5.3 & 5.3 \\
Malaysia & 5.9 & 4.9 & 4.8 & 4.6 & 5.1 \\
Filipina & 6.7 & 6.4 & 6.5 & 6.6 & 6.6 \\
Thailand & 3.9 & 4.5 & 4.1 & 3.7 & 3.4 \\
Vietnam & 6.8 & 6.9 & 6.7 & 6.5 & 5.9 \\
Brunei Darussalam dan Singapura & & & & -1.3 \\
Brunei Darussalam & 1.3 & 2.0 & 2.3 & 2.0 & 3.5 \\
Singapura & 3.6 & 3.5 & 2.9 & 2.7 & 7.1 \\
CLM countries & & & & & 7.6 \\
Kamboja & 7.0 & 7.0 & 6.9 & 6.9 & 7.3 \\
Laos & 6.9 & 6.6 & 6.8 & 7.0 & 7.3 \\
Myanmar & 6.8 & 6.6 & 6.9 & & 5.1 \\
Cina & & & & & \\
Cina & 6.9 & 6.6 & 6.3 & 5.9 & \\
Rata-rata ASEAN & 5.3 & 5.3 & 5.2 & 5.2 & \\
\hline Rata-rata dari & 6.5 & 6.6 & 6.3 & 6.1 & \\
Emerging Asia & & & & & \\
\hline
\end{tabular}

Sumber: OECD Development Centre, Medium-term Projection Framework (MPF), 2019

Bank Dunia baru-baru ini melaporkan bahwa mereka mengharapkan ekonomi global tumbuh lebih kuat dari yang diperkirakan yaitu 3,1\%, dengan percepatan lebih dari setengah ekonomi. Menurut laporan Dewan Kebijakan Bisnis Global, ini adalah pertama kalinya sejak Krisis Keuangan Global (GFC) bahwa ekonomi global berada pada kenaikan yang sinkron. Prospek positif datang ketika ekonomi global mengalami pemulihan siklus, yang mencerminkan peningkatan umum dalam investasi, aktivitas 
manufaktur, dan perdagangan. Tren kenaikan ini merupakan berita baik bagi ekonomi yang bergantung pada perdagangan, terutama di kawasan ASEAN, karena peningkatan perdagangan internasional akan membuat kemajuan untuk investasi yang lebih pasti. Produksi manufaktur yang tinggi menunjukkan bahwa terjadi peningkatan impor dan ekspor dalam rantai pasokan global dan tingkat pertumbuhan layanan yang lebih tinggi. Pasar ASEAN telah tumbuh dengan stabil pada tingkat 5\% selama beberapa tahun terakhir [21].

Tabel 3. Pertumbuhan Ekonomi ASEAN Tahun 2018

\begin{tabular}{ccccc}
\hline Negara & $\begin{array}{c}\text { PDB pada harga saat } \\
\text { ini (US\$b) }\end{array}$ & $\begin{array}{c}\text { Produk Domestik } \\
\text { Bruto (GDP) per } \\
\text { kapita (US\$) }\end{array}$ & $\begin{array}{c}\text { Pertumbuhan nyata } \\
\text { Produk domestik } \\
\text { Bruto (GDP) }(\%)\end{array}$ & $\begin{array}{c}\text { Tingkat inflasi, } \\
\text { rata-rata }(\%)\end{array}$ \\
\hline $\begin{array}{c}\text { Darunei } \\
\text { Kambalam }\end{array}$ & 13.6 & $31,895.1$ & 0.1 & 0.2 \\
Indonesia & 24.5 & $1,535.5$ & 7.0 & n.a \\
Laos & $1,041.6$ & $3,928.72$ & 5.2 & 3.2 \\
Malaysia & 18.1 & $2,627.8$ & 6.7 & 0.9 \\
Myanmar & 354.2 & $10,907.7$ & 4.8 & 6.9 \\
Filipina & 71.5 & $1,328.2$ & 6.4 & 5.3 \\
Singapura & 342.6 & $3,213.3$ & 6.2 & 0.4 \\
Thailand & 361.0 & $64,273.9$ & 3.3 & 1.1 \\
Vietnam & 505.1 & $7,443.5$ & 4.1 & 3.5 \\
ASEAN & 240.7 & $2,542.6$ & 7.1 & $0.2-6.9$ \\
\hline
\end{tabular}

Sumber: Ref [22]

Dorongan fiskal dan moneter harus tetap menjaga permintaan domestik agar tetap stabil, sementara banyak sektor eksternal terlihat pulih dari kinerja 2019 yang tergolong lesu. Perkembangan dalam negosiasi perdagangan AS dan China akan tetap menjadi faktor penting untuk prospek, mengingat ketergantungan kawasan terhadap perdagangan. Menurut data awal, inflasi regional naik menjadi 2,5\% pada bulan Desember dari 2,2\% pada bulan November, sebagian besar disebabkan oleh kenaikan tekanan inflasi di Laos, Filipina, Singapura, Thailand, dan Vietnam. Inflasi rata-rata regional diperkirakan akan naik lebih tinggi pada Tahun 2020 karena biaya pinjaman yang lebih rendah, stimulus fiskal, dan permintaan domestik yang kuat [23].

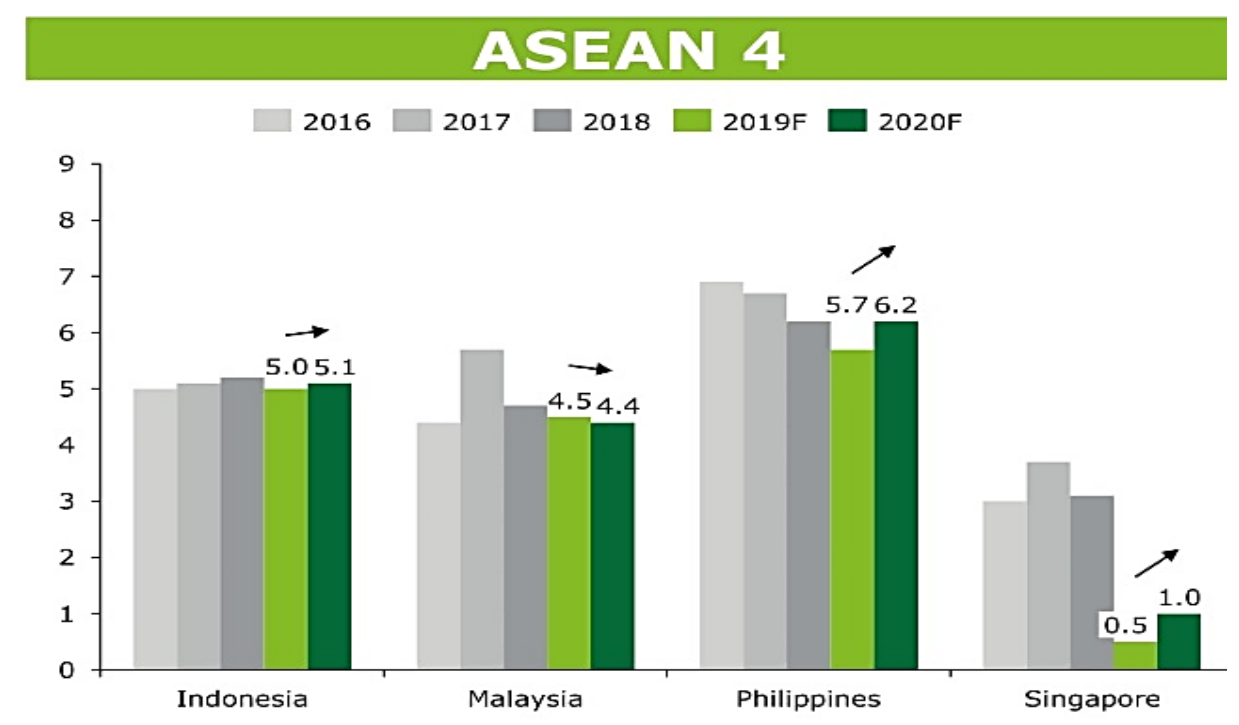

Gambar 2. Kurva pertumbuhan ekonomi Indonesia, Malaysia, Filipina, dan Singapura. Sumber: IMF WEO, 2020.

Gambar 2 memperlihatkan Indonesia menunjukkan pertumbuhan yang baik pada Tahun 2019 dan 2020. Meskipun terjadi ketidakpastian global, namun prospek ekonomi tetap positif dengan permintaan domestik menjadi pendorong utama pertumbuhan. Malaysia menunjukkan pertumbuhan mereda pada 2019 dan 2020. Permintaan domestik yang menguntungkan, khususnya rumah tangga pengeluaran karena 
pasar tenaga kerja yang stabil, dan inflasi yang rendah. Di tengah meningkatnya ketidakpastian global, ekonomi Filipina masih tetap kuat. Hal tersebut terlihat dari peningkatan pertumbuhan ekonominya pada Tahun 2020. Singapura menunjukkan tren pertumbuhan menurun pada 2020. Hal tersebut dipengaruhi oleh penurunan siklus elektronik dan ketegangan AS-Cina [24]. Sementara untuk negara lainnya seperti Kamboja, Laos, Myanmar, dan Vietnam dapat dilihat pada Gambar 3.

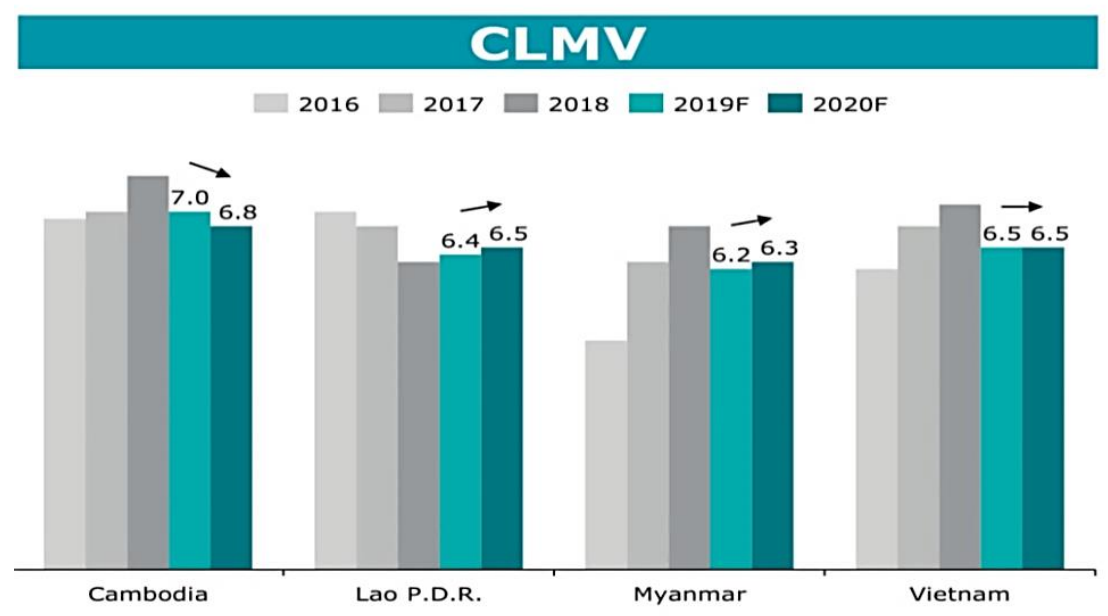

Gambar 3. Kurva pertumbuhan ekonomi Kamboja, Laos, Myanmar, Vietnam Sumber: IMF WEO, 2020.

Gambar 3 menunjukkan Kamboja menunjukkan fiskal yang relatif besar (lebih dari 3\% dari PDB) diharapkan akan diperkenalkan pada Tahun 2020 untuk mengurangi dampak negatif potensial dari penarikan EBA. Laos menunjukkan pertumbuhan di sektor konstruksi dan jasa diperkirakan akan tetap kuat dalam jangka menengah karena investasi infrastruktur yang berkelanjutan. Myanmar menunjukkan risiko kerugian mendominasi ekonomi Myanmar, yang meliputi ketidakpastian ekonomi global, krisis Rakhine, dan domestik konflik. Sentimen ekonomi Vietnam tetap terekspos secara global, mengingat tingginya perdagangan terbuka dan penyangga kebijakan yang terbatas. Pertumbuhan diperkirakan akan lebih moderat di Tahun 2020 dan 2021 ke kecepatan yang lebih berkelanjutan 6,5\% [24].

Demografi dan Urbanisasi

Urbanisasi merupakan dinamika terpenting dalam perekonomian Asia Tenggara. Infografis pertama ini merinci evolusi populasi negara-negara ASEAN dan ASEAN dalam beberapa tahun dan dekade mendatang. Asia Tenggara secara keseluruhan siap untuk melihat pertumbuhan demografis yang cepat di sebagian besar negara. Proyeksi yang tercantum pada Gambar 4 terutama menyoroti pertumbuhan demografis penting ASEAN, dari 630 juta pada 2015, menjadi 660 juta penduduk pada 2020, 720 juta pada 2030, dan lebih banyak 785 juta pada 2050. Pertumbuhan populasi tertinggi ditunjukkan oleh Indonesia dan Filipina.

\begin{tabular}{|c|c|c|c|c|}
\hline $\begin{array}{l}\text { Population } \\
\text { in millions }\end{array}$ & 2015 & 2020 & 2030 & 2050 \\
\hline (8) ASEAN & 632 & 665 & 721 & 785 \\
\hline Brunei & 0.43 & 0.45 & 0.50 & 0.55 \\
\hline Cambodia & 16 & 17 & 19 & 23 \\
\hline Indonesia & 256 & 269 & 293 & 321 \\
\hline - Laos & 7.02 & 7.65 & 8.81 & 10.6 \\
\hline 定 Malaysia & 31 & 33 & 37 & 42 \\
\hline Myanmar & 54 & 56 & 59 & 59 \\
\hline Philippines & 102 & 110 & 128 & 157 \\
\hline Singapore & 5.62 & 6.05 & 6.58 & 7.06 \\
\hline EThailand & 67 & 68 & 68 & 62 \\
\hline$\star$ Vietnam & 93 & 97 & 102 & 104 \\
\hline
\end{tabular}

Gambar 3. Pertumbuhan demografi ASEAN Sumber: Ref. [25] 
Negara-negara ASEAN, secara keseluruhan berada dalam tahap transisi demografis yang lebih maju menuju rasio ketergantungan yang lebih rendah. Disisi lain Cina mendekati akhir kenaikan demografiknya dan akan mengalami defisit demografis. Di banyak negara ASEAN, tingkat kematian dan kesuburan yang rendah, bersama dengan populasi orang dewasa usia kerja yang tumbuh dengan cepat, akan memberikan beberapa peluang untuk pertumbuhan PDB yang luar biasa dalam 20 hingga 30 tahun ke depan. Di Asia Tenggara, tingkat pertumbuhan populasi yang relatif stabil pada kurang dari $1 \%$ per tahun melonjak antara Tahun 1950 dan 1990 menjadi lebih dari 2\%. Pada tingkat ini, populasi usia kerja di Asia Tenggara akan mencapai 68\% dari total populasi di kawasan ini pada Tahun 2025 dan kurang dari $60 \%$ pada Tahun 1990. Di samping perubahan ini, rasio ketergantungan telah semakin meningkat dengan cepat ketika ketergantungan kaum muda turun dari 0,77 ke 0,60 [26].

Urbanisasi mengacu pada peningkatan pangsa total populasi yang tinggal di daerah perkotaan, yaitu daerah yang secara administratif didefinisikan sebagai perkotaan, tetapi kenyataannya jauh lebih kompleks. Populasi perkotaan tidak statis, karena migran masuk dan keluar, tinggal dalam waktu yang lebih pendek atau lebih lama, melakukan perjalanan tunggal atau kembali secara teratur. Jika mereka menetap di kota, mereka tidak selalu mendaftar, dan hal ini dapat menyebabkan perbedaan yang signifikan. Menurut Administrasi Metropolitan Bangkok [27], populasi Bangkok adalah 5,7 juta pada 2010, tetapi Kantor Statistik Nasional menghitung 8,2 juta dalam sensus tahun itu [28]. Perbandingan data populasi resmi dan pertumbuhan izin bangunan, lapangan kerja, dan pendaftaran sepeda motor menemukan bahwa populasi Kota Ho Chi Minh pada Tahun 2007 kemungkinan sebesar 8,7 juta dari angka resmi 6,6 juta [29].

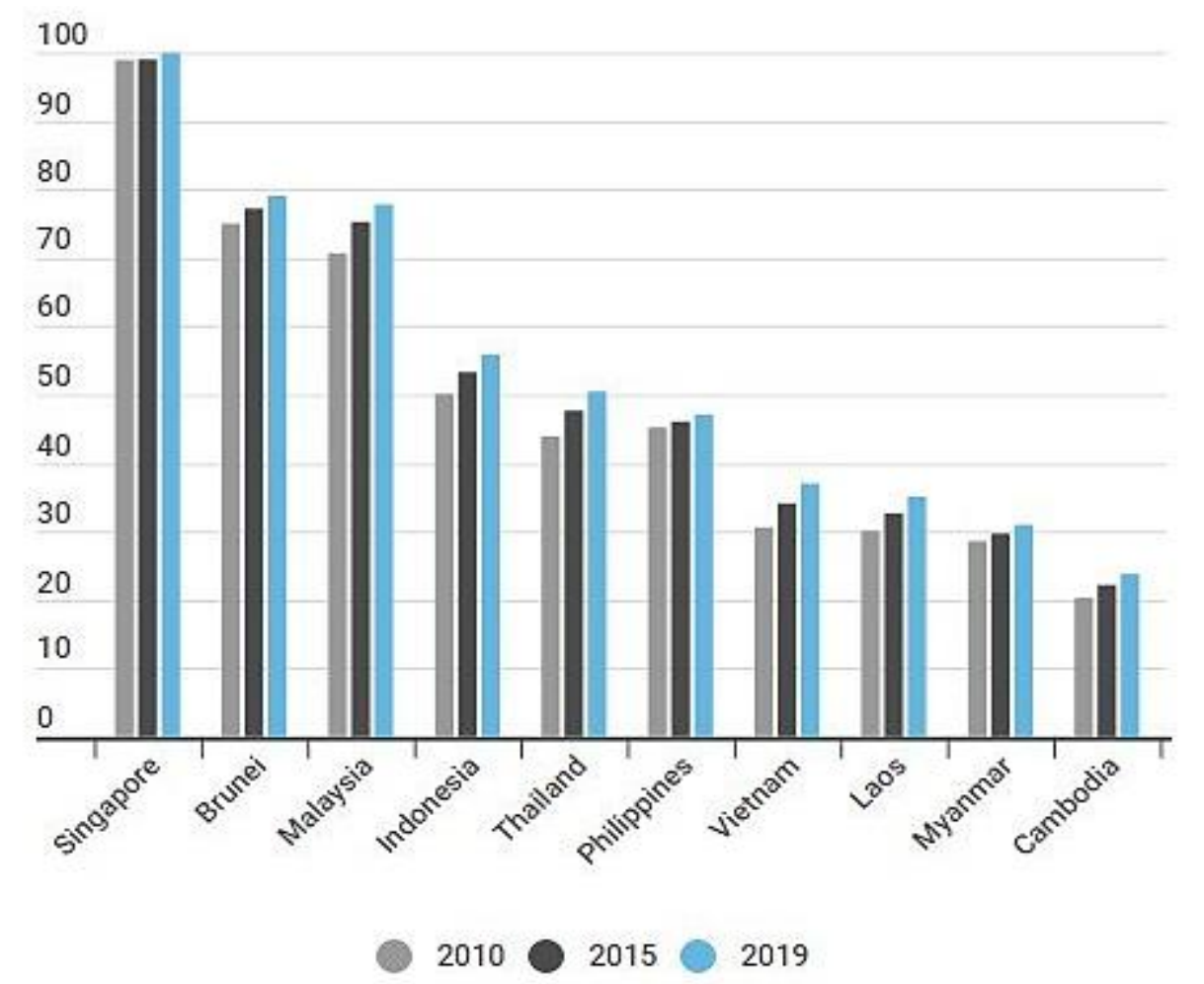

Gambar 4. Persentase Kehidupan Populasi Di Lingkungan Urban Sumber: Worldometers, 2019

Globalisasi dan perdagangan bebas mendorong ekonomi ASEAN dan mereka mendukung kotakota pesisir. Jadi, pertumbuhan ekonomi dan pertumbuhan populasi hanya terpusat di satu atau dua kota besar per negara seperti, Bangkok, Jakarta, Kota Ho Chi Minh, Kuala Lumpur, dan Manila. Pada Tahun 2015, ASEAN secara resmi memiliki dua kota besar dengan populasi lebih dari 10 juta [30] yaitu Manila (12,9 juta) dan Jakarta (10,3 juta), tetapi wilayah yang dibangun jauh lebih besar dan membentang jauh melampaui batas kota. Sebagian besar populasi "perkotaan" tinggal di luar wilayah perkotaan yang ditentukan secara administratif. Menurut Ref. [31], berdasarkan "area terbangun" diperkirakan populasi Jakarta adalah 31,8 juta dan Manila sebesar 24,3 juta pada 2017.

Kesenjangan yang lebar dalam pembangunan antara berbagai bagian suatu negara tidak diinginkan secara sosial dan politik, dan para politisi dan perencana tata ruang sering kali meminta distribusi yang 
lebih merata. Seruan-seruan semacam itu cenderung bertentangan dengan para ekonom yang berpendapat bahwa demi efisiensi, pasar harus menentukan dimana investasi dan tenaga kerja bergerak, bahkan jika ini memusatkan pertumbuhan ekonomi di satu atau dua kota yang sangat besar [32]. Pengambilan keputusan politik terpusat memperkuat tren ini, karena bisnis di Asia Tenggara lebih suka untuk bertatap muka dengan para pembuat keputusan. Perbedaan mungkin menurun seiring waktu, karena biaya tanah dan tenaga kerja naik lebih cepat di kota-kota besar daripada di kota-kota kecil dan teknologi transportasi dan komunikasi yang canggih mengurangi jarak antar tempat. Di Thailand, pembangunan ekonomi menyebar di luar Bangkok dan sekitarnya, Utara dan Timur Laut, meskipun ini masih merupakan bagian paling miskin di negara ini.

Pada 2019, Asia-Pasifik menjadi populasi perkotaan mayoritas untuk pertama kalinya dalam sejarah. Menurut laporan terbaru dari Perserikatan Bangsa-Bangsa, akan ada 1,2 miliar penduduk kota baru di wilayah ini pada Tahun 2050. Lonjakan tajam penduduk perkotaan ini akan mengubah ekonomi, masyarakat, dan lingkungan regional. Dengan prospek perubahan yang cepat, pembuat kebijakan perlu mulai mengembangkan kapasitas kota untuk ketahanan. Hal-hal seperti manajemen sumber daya dan infrastruktur, risiko bencana, dan ketidaksetaraan dapat secara substansial mengganggu keberlanjutan kota. Namun demikian, potensi pembaruan ekonomi dan sosial tetap ada [33].

\section{Kualitas Udara, Risiko Iklim, dan Degradasi Lingkungan}

Akses ke udara bersih adalah penentu utama kesehatan manusia, serta kondisi keseluruhan organisme lain dan proses lingkungan. Polusi udara luar ruang adalah produk sampingan umum dari produksi industri, transportasi bermotor, dan pada kenyataannya proses sentral yang menopang pertumbuhan ekonomi global selama sekitar satu abad terakhir. Di sisi lain, polusi udara dalam ruangan sering dikaitkan dengan kekurangan pembangunan. Tidak adanya alternatif yang terjangkau mendorong pembakaran bahan bakar padat seperti kotoran dan kayu untuk energi, meskipun memiliki efek berbahaya. Polusi udara merupakan masalah utama yang terjadi di kota-kota berkembang di Asia yang menyebabkan penyakit pernapasan hingga kematian. Sifat luas dari masalah ini merongrong produktivitas dan pendapatan angkatan kerja, yang menyebabkan banyak kerugian ekonomi. Sebagai contoh, sebuah studi terbaru memperkirakan bahwa pada Tahun 2005 kesejahteraan mengalami penurunan terkait dengan polusi udara di Tiongkok yaitu sekitar \$151 miliar (dolar 2010) [34].

Polusi udara umumnya melebihi tingkat aman di kota-kota Asia yang sedang berkembang. Emisi gas beracun dan bahan partikulat dari kendaraan bermotor, industri, dan penyebab lain menjadi pemicu meningkatnya polusi udara di perkotaan yang dapat meningkatkan risiko penyakit pernapasan dan kanker [35]. Secara global, diperkirakan 65\% kematian akibat polusi udara perkotaan terjadi di Asia [36]. Pada tingkat agregat ada peningkatan yang signifikan dalam beberapa waktu terakhir [37], tetapi tanpa upaya mitigasi yang diperbarui, seperti standar emisi yang lebih ketat dan program pemantauan yang lebih kuat, situasinya di seluruh wilayah dapat memburuk secara substansial.

Penurunan kualitas udara di Asia Tenggara, yang disebabkan oleh kebakaran hutan di sebagian wilayah Indonesia dan sub-wilayah Mekong, telah menimbulkan pertanyaan tentang efektivitas perjanjian ASEAN untuk mencegah polusi kabut asap. Perjanjian ASEAN tentang Polusi Asap Lintas Batas adalah perjanjian lingkungan yang mengikat secara hukum yang diterapkan untuk semua 10 negara anggota ASEAN, yang ditandatangani pada Tahun 2002, untuk mengurangi polusi kabut asap terutama melalui kegiatan pemantauan dan pencegahan. Indonesia adalah negara terakhir yang meratifikasi Perjanjian ASEAN tentang Polusi Asap Lintas Batas (AATHP) dan menyerahkan dokumen ratifikasi ke Sekretariat ASEAN pada Januari 2015 [38].

Menurut Indeks Risiko Iklim Global, empat dari sepuluh negara di dunia yang paling terpengaruh oleh perubahan iklim terletak di Asia Tenggara yaitu Myanmar, Filipina, Thailand, dan Vietnam. Negara tetangga Bangladesh juga berada di peringkat sepuluh besar [39]. Demikian pula, Indeks Kerentanan Iklim mengklasifikasikan populasi dan ekosistem kawasan sebagai "sangat" atau "sangat" rentan terhadap perubahan iklim[40]. Geografi khusus Asia Tenggara membuat kemungkinan bahwa perubahan iklim akan memengaruhi hubungan antar negara. Daerah ini memiliki perbatasan internasional yang rumit, seperti diantaranya Thailand dan tetangganya, atau di pulau Kalimantan / Kalimantan, yang terbagi antara Brunei Darussalam, Indonesia, dan Malaysia. Indonesia terdiri dari lebih dari 17.000 pulau dan Filipina memiliki lebih dari 7000 pulau. Saham Myanmar langsung perbatasan darat dengan kekuatan besar Cina dan India, Laos dan Vietnam berbatasan dengan Cina, dan Brunei Darussalam, Indonesia, Malaysia, dan Filipina semua memiliki perbatasan laut dengan Cina. Kompleksitas geografis tersebut menimbulkan banyak risiko perkembangan terkait iklim meluas dari satu negara ke negara lain, tetapi juga peluang untuk negara dalam mengoordinasikan mitigasi iklim mereka dan langkah-langkah adaptasi [41]. Indeks 
Resiko Iklim Global memberi peringkat kerentanan masing-masing negara ASEAN terhadap perubahan iklim seperti yang terlihat pada Tabel 4.

Tabel 4. Peringkat resiko iklim di negara ASEAN

\begin{tabular}{c} 
Myanmar \\
Philippines \\
Vietnam \\
Thailand \\
Cambodia \\
Indonesia \\
Laos \\
Malaysia \\
Brunei Darussalam \\
Singapore \\
\hline Sumber: Ref. [39]
\end{tabular}

\section{Akses, Keterjangkauan Dan Keamanan Energi}

Negara-negara ASEAN memiliki tantangan bersama mengenai keamanan energi, yaitu memenuhi permintaan energi yang meningkat dengan cara yang aman, terjangkau, dan berkelanjutan. Dengan memperluas model gravitasi dan spesifikasi model dapat memperkenalkan serangkaian variabel kunci untuk menangkap penyebaran energi terbarukan, efisiensi energi, dan tingkat integrasi ekonomi regional. Tiga langkah penting dalam tantangan ini yaitu memastikan pasokan energi terbarukan, peningkatan efisiensi energi, dan integrasi ekonomi yang lebih kuat. Dengan menggunakan data tahunan di 440 negara selama periode 1995-2016 yang menunjukkan peran pasokan energi terbarukan, peningkatan efisiensi energi, dan integrasi ekonomi dalam perdagangan energi bilateral. Berdasarkan temuan tersebut, rekomendasi kebijakan disediakan untuk membantu pengambil keputusan ASEAN menentukan kebijakan keamanan energi di masa depan [42].

Asia Tenggara adalah kawasan yang sangat berpotensi sebagai energi global, dengan kecepatan permintaan energi tumbuh dua kali lipat dari Cina. Masa sekarang hingga 2040, permintaan energi di kawasan itu diperkirakan akan tumbuh hampir dua pertiga, yang berkontribusi terhadap 12\% dari permintaan global. Pada saat yang sama, ekonomi regional akan lebih dari tiga kali lipat, dan populasi akan naik seperlima, dengan populasi perkotaan saja tumbuh lebih dari 150 juta orang. Ada perbedaan besar dalam situasi dan tren energi diantara sepuluh negara ASEAN. Brunei Darussalam ukurannya serupa dengan Luksemburg dalam hal populasi (kurang dari 0,5 juta) dan penggunaan energi per kapita, yang melebihi rata-rata negara-negara anggota IEA sebesar 45\%, sementara Kamboja, Myanmar, dan Filipina masih dibawah seperdelapan dari rata-rata IEA. Namun secara bersamaan, penggunaan energi per kapita kini telah mencapai sekitar setengah dari rata-rata dunia, menunjukkan ruang lingkup yang besar untuk pertumbuhan permintaan energi di masa depan [43].

Indonesia memiliki permintaan energi tertinggi, terhitung lebih dari $35 \%$ dari total wilayah, diikuti oleh Thailand. Bahan bakar fosil mendominasi energi primer di kawasan tersebut, terhitung hampir 75\% dari total pada 2016. Pangsa ini diperkirakan akan tetap stabil hingga 2040. Namun, Asia Tenggara akan berubah dari daerah ekspor bersih menjadi daerah yang akan perlu mengimpor untuk memenuhi permintaan energinya yang terus meningkat. Permintaan minyak akan naik sekitar $40 \%$ dan konsumsi gas alam hampir $60 \%$, sementara produksi minyak turun sepertiga dan gas produksi hampir tetap level. Batubara sendiri menyumbang hampir $40 \%$ dari permintaan energi pertumbuhan dan menyusul gas dalam campuran listrik. Energi rendah karbon juga tumbuh dengan kuat. Pangsa energi terbarukan akan hampir berlipat ganda karena penyebarannya membantu memenuhi kenaikan listrik menuntut dan memperluas akses energi [43].

Masih terbatasnya akses penggunaan listrik dan bahan bakar memasak modern merupakan bentuk dari kemiskinan energi. Akses ke energi modern membutuhkan teknologi dan instrumen dan sumber pembiayaan yang lebih baik. Model kemitraan publik-swasta yang berpihak pada masyarakat miskin adalah motor penggerak yang berguna untuk meningkatkan modal investasi. Lima faktor tampaknya diperlukan dalam kombinasi untuk program dan kemitraan untuk berhasil mempromosikan akses energi dan memberantas kemiskinan energi yaitu memilih teknologi yang tepat, mempromosikan partisipasi masyarakat, menekankan pemeliharaan dan layanan, menggabungkan layanan dengan pendapatan, dan membangun kapasitas lokal [44].

Wilayah ASEAN diberkahi dengan sumber daya energi konvensional, yaitu minyak, gas, dan batubara. Namun sumber daya tersebut tidak merata diantara negara-negara dan kadang-kadang terletak 
jauh dari pusat-pusat permintaan. Berdasarkan Ref. [45], pada Tahun 2015, wilayah ASEAN menghasilkan total 2,4 juta barel minyak per hari dan produksi minyak diperkirakan akan menurun pada tingkat 1,4\% per tahun dari 2015 hingga 2040, yang menghasilkan 1,6 juta barel produksi minyak per hari pada Tahun 2040. Tren penurunan ini terutama disebabkan oleh ladang minyak yang berada dalam fase penurunan. Adapun produksi gas alami wilayah ASEAN telah menghasilkan total 205 miliar meter kubik gas alam pada Tahun 2015 dan volume itu diperkirakan akan menurun pada tingkat $0,6 \%$ per tahun mencapai 177 miliar meter kubik pada Tahun 2040. Perlu dicatat bahwa tren produksi gas alam bervariasi diantara negara-negara anggota, misalnya produksi gas alam tahunan di Brunei Darusssalam diperkirakan akan stabil sedangkan produksi di Indonesia diperkirakan akan menghadapi tren yang sedikit menurun dan produksi gas alam Vietnam diharapkan meningkat. Akhirnya, produksi batubara di kawasan ASEAN diperkirakan akan meningkat pada Tahun 2040, sebesar 487 juta ton dari 434 juta ton batubara pada Tahun 2015. Mayoritas produksi batubara berasal dari Indonesia.

Terlepas dari melimpahnya bahan bakar fosil konvensional, wilayah ini juga relatif diberkahi dengan sumber energi terbarukan terutama dalam hidro dan matahari serta jenis energi terbarukan lainnya, meskipun tingkat dan jenis energi terbarukan mungkin berbeda dari satu negara ke negara lain. Wilayah ini telah menetapkan target untuk berkontribusi $23 \%$ dari pasokan energi primernya dari energi terbarukan pada Tahun 2025 [7]. Total permintaan energi final, total pasokan energi primer, dan total produksi listrik oleh negara-negara anggota ASEAN antara 2015 dan 2050 dapat dilihat pada Tabel 5.

Tabel 5. Total permintaan energi, total pasokan energi primer, dan total produksi listrik

\begin{tabular}{lcccccccccccc}
\hline & \multicolumn{3}{c}{$\begin{array}{c}\text { Total keseluruhan kebutuhan } \\
\text { energi (Mtoe) }\end{array}$} & \multicolumn{3}{c}{$\begin{array}{c}\text { Total Pasokan Energi Primer } \\
\text { (Mtoe) }\end{array}$} & \multicolumn{4}{c}{$\begin{array}{c}\text { Produksi Listrik Total } \\
\text { (TWh) }\end{array}$} \\
& 2015 & 2030 & 2040 & 2050 & 2015 & 2030 & 2040 & 2050 & 2015 & 2030 & 2040 & 2050 \\
\hline Indonesia & 163 & 245 & 314 & 382 & 225 & 394 & 511 & 619 & 234 & 520 & 762 & 1035 \\
Thailand & 98 & 122 & 144 & 168 & 135 & 174 & 210 & 245 & 178 & 260 & 341 & 422 \\
Vietnam & 58 & 96 & 128 & 167 & 74 & 128 & 178 & 240 & 153 & 320 & 487 & 716 \\
Philippines & 30 & 58 & 82 & 114 & 52 & 97 & 132 & 175 & 82 & 186 & 287 & 434 \\
Malaysia & 52 & 71 & 82 & 92 & 86 & 120 & 142 & 158 & 150 & 250 & 321 & 388 \\
Myanmar & 18 & 31 & 43 & 59 & 20 & 35 & 50 & 69 & 16 & 66 & 103 & 149 \\
Other ASEAN & 17 & 22 & 24 & 24 & 29 & 34 & 36 & 38 & 55 & 68 & 73 & 76 \\
\hline
\end{tabular}
Sumber: IEEJ, 2018 [46]

Tabel 5 menunjukkan bahwa pada Tahun 2050, Indonesia, Thailand, dan Vietnam memiliki total permintaan energi final tertinggi dengan 382Mtoe, 168Mtoe, dan 167Mtoe, masing-masing diikuti oleh Filipina, Malaysia, dan Myanmar masing-masing dengan 114Mtoe, 92Mtoe, dan 59Mtoe. Secara keseluruhan, negara-negara anggota ASEAN menunjukkan peningkatan permintaan energi final antara 2015 dan 2050. Dalam hal pembangkit listrik, pada 2015 Indonesia adalah produsen listrik terbesar di kawasan ini dengan total listrik yang dihasilkan adalah 234TWh dan diproyeksikan akan meningkat lebih dari empat kali lipat pada Tahun 2050 hingga 1.035TWh. Penghasil listrik terbesar kedua di wilayah ini adalah Thailand, diikuti oleh Vietnam, Malaysia, Filipina, Myanmar, dan negara ASEAN lainnya. Impor energi bersih oleh masing-masing negara anggota ASEAN antara 2010 dan 2030 dapat dilihat pada Tabel 6. Negara dengan impor bersih negatif mencerminkan bahwa negara tersebut merupakan negara pengekspor neto. Indikator ini membantu menentukan kemungkinan mengamankan pasokan energi di kawasan melalui interkoneksi infrastruktur energi yang ada dan yang akan datang.

Tabel 6. Impor batubara, migas, dan listrik

\begin{tabular}{lcccccccccccc}
\hline & \multicolumn{3}{c}{$\begin{array}{c}\text { Impor Batubara } \\
\text { Bersih } \\
\text { (Mtoe) }\end{array}$} & $\begin{array}{c}\text { Impor Minyak Bersih } \\
\text { (Mtoe) }\end{array}$ & \multicolumn{3}{c}{$\begin{array}{c}\text { Impor Gas Alam Bersih } \\
\text { (Mtoe) }\end{array}$} & $\begin{array}{c}\text { Impor Listrik Bersih } \\
\text { (Mtoe) }\end{array}$ \\
& 2010 & 2020 & 2030 & 2010 & 2020 & 2030 & 2010 & 2020 & 2030 & 2010 & 2020 & 2030 \\
\hline Brunei Darussalam & 0 & 0 & 0 & 7.54 & -6.66 & -5.09 & -7.99 & -7.1 & -5.6 & 0 & 0 & 0 \\
Indonesia & -142 & -196 & -279 & 19.28 & 53.63 & 98.74 & -27.06 & -6.5 & 36.2 & 0 & 0 & 0 \\
Thailand & 10.02 & 14.95 & 17.56 & 34.5 & 49.32 & 69.74 & 4.16 & 11.2 & 19.3 & 0.49 & 2.63 & 3.85 \\
Malaysia & 9.37 & 14.05 & 11.99 & -7.7 & 11.45 & 25.16 & -21.81 & -36 & -32 & -0 & -0 & -0.02 \\
Philippines & 2.87 & 7.74 & 18.59 & 13.72 & 17.1 & 25.14 & 0 & 0 & 0 & 0 & 0 & 0 \\
Singapore & 0.12 & 0.63 & 0.49 & 56.8 & 72.15 & 85.13 & 7.82 & 8.91 & 9.5 & 0 & 0 & 0 \\
Vietnam & -7.7 & -4.03 & 7.45 & -2.96 & 6.48 & 23.09 & 0.22 & -1.7 & 9.34 & 0.48 & 0.69 & 0.69 \\
\hline
\end{tabular}

Sumber: APERC, 2013 [47] 
Berdasarkan Tabel 6, Indonesia tetap menjadi eksportir batubara utama di wilayah ini antara 2010 dan 2030. Di sisi lain, Thailand, Malaysia, Filipina, dan Singapura adalah importir bersih batubara hingga 2030. Brunei Darussalam diproyeksikan akan tetap sebagai eksportir minyak netto antara 2010 dan 2030 dan negara-negara anggota ASEAN lainnya tetap sebagai importir minyak bersih pada 2030. Malaysia dan Vietnam akan mengubah posisinya dari eksportir minyak bersih pada 2010 menjadi importir minyak bersih pada 2020. Dalam hal gas alam, Brunei Darussalam dan Malaysia diperkirakan akan tetap sebagai eksportir bersih antara 2010 dan 2030. Namun, Indonesia dan Vietnam diperkirakan akan mengubah posisi mereka dari eksportir bersih gas alam pada Tahun 2020 menjadi importir bersih gas alam pada Tahun 2030. Thailand dan Singapura diperkirakan akan tetap sebagai importir gas alam. Pada impor listrik bersih, Thailand dan Vietnam diproyeksikan tetap sebagai importir bersih listrik hingga Tahun 2030. Di sisi lain, Malaysia akan tetap sebagai eksportir listrik bersih yang tidak signifikan [48].

\section{Investasi dan Pembiayaan}

Ekonomi digital ASEAN telah berkembang pesat, didukung oleh jaringan digital yang berkembang pesat dan jumlah pengguna ponsel dan internet. ASEAN memiliki jumlah pengguna internet terbesar ketiga di dunia setelah Cina dan India. Partisipasi aktif wilayah ini dalam pengembangan digital dan promosi investasi dalam infrastruktur teknologi informasi dan komunikasi (TIK) adalah pendorong utama pertumbuhan ini. Ekonomi internet (transaksi yang dilakukan secara online) diperkirakan bernilai \$50 miliar pada Tahun 2017 dan diharapkan menjadi ekonomi \$200 miliar pada Tahun 2025. Namun, untuk memenuhi potensi ini, diperlukan kebijakan dan kerangka kerja regulasi yang tepat untuk mendorong partisipasi dan investasi lebih lanjut oleh sektor swasta. Hal ini juga membutuhkan penanganan berupa tantangan dan potensi kelemahan terkait dengan pertumbuhan ekonomi digital yang cepat [49].

Meningkatkan konektivitas digital dan investasi ke dalam ruang digital ASEAN untuk mendukung basis konsumen yang berkembang di kawasan ini, dapat meningkatkan potensi rantai pasokan kawasan dan meningkatkan tarikan gravitasi untuk perusahaan multi-nasional dan perusahaan. Masterplan tentang Konektivitas ASEAN 2025 telah menyatakan hal tersebut \$220 miliar hingga \$650 miliar dalam dampak ekonomi tahunan tambahan di ASEAN pada Tahun 2030 dapat disuntikkan ke ASEAN melalui teknologi baru dan ekonomi internet [50]. Potensinya dipahami dengan jelas oleh perusahaan-perusahaan AS, Cina, dan Jepang yang berinvestasi dalam teknologi informasi dan komunikasi (TIK) selama dua tahun terakhir. Tetapi kemajuan digital ASEAN masih beragam [51]. Misalnya, di lima negara ASEAN, E-Commerce mewakili dibawah 3\% atau kurang dari total penjualan ritel, dibandingkan dengan Cina dengan 23\% [52]. Namun ada titik terang. Anggota ASEAN menandatangani Perjanjian ASEAN tentang E-Commerce pada bulan November untuk pertama kali di dunia [53]. Namun, mengubah perjanjian menjadi bukti fisik seperti infrastruktur pembayaran elektronik regional atau memungkinkan pergerakan bisnis lintas batas, kolaborasi keamanan cyber untuk menanamkan kepercayaan konsumen dan pemerintah, dan pengembangan rezim akses pasar sangat penting.

Daya tarik Perhimpunan Bangsa Bangsa Asia Tenggara (ASEAN) sebagai kawasan ekonomi modern yang lebih terintegrasi dapat dikaitkan dengan banyak faktor termasuk eksekusi yang tak kenal lelah dan datang bersama berbagai kebijakannya, memperdalam kerja sama Negara Anggota ASEAN (AMS), keterbukaan untuk berdialog, dan perbaikan menyeluruh berkelanjutan dalam kemudahan melakukan bisnis [54] yang mewakili kebijakan dalam praktik pasar. Daya tarik paling baik dibuktikan dengan pertumbuhan FDI yang stabil ke ASEAN yang mencapai ketinggian \$137 miliar pada Tahun 2017, bagian yang mengesankan 20\% dari semua FDI global untuk pengembangan ekonomi. FDI juga beragam dari manufaktur menjadi layanan ritel dan nilai tambah baru industri seperti kesehatan, R\&D, dan E-Commerce [55]. Kebijakan dan inisiatif pertumbuhan baru untuk diperhatikan pada 2018 dan awal 2019, kebijakan berwawasan ke depan baru terus diperkenalkan yang sangat relevan dengan komunitas global peserta ASEAN. Misalnya, kerangka kerja ASEAN tingkat tinggi tentang Elektronic Commerce [55] setuju untuk mengenali dan mendorong AMS kerjasama untuk membangun E-Commerce lintas batasnya fitur termasuk perdagangan tanpa kertas, interoperable otentikasi elektronik dan tanda tangan elektronik untuk meminimalkan hambatan terhadap arus informasi. Itu diikuti oleh survei tata kelola data ASEAN untuk sektor swasta ke mengkalibrasi kebijakan terkait data. Letter of Intent telah ditandatangani antara bank sentral Thailand, Malaysia, Indonesia, dan Filipina untuk memulai diskusi tentang suatu pembentukan kerangka kerja penyelesaian mata uang lokal yang akan memfasilitasi E-Commerce lintas batas yaitu diantisipasi pada akhir 2019 [56]. Sebagai langkah awal, pusat bank juga bekerja pada pembayaran instan lintas batas dengan hubungan langsung pertama antara Thailand dan Singapura diharapkan pada Tahun 2020. 


\section{Kebijakan Energi, Harga, dan Regulasi}

Energi memegang peran sentral dan posisi strategis dalam sektor sosial, ekonomi, budaya, dan politik yang menggerakkan roda peradaban dengan menopang semua kebutuhan masyarakat. Energi dapat dimanfaatkan untuk kegiatan yang berkaitan dengan pembangkit listrik, pendinginan, dan pemanasan [57,58]. Energi juga digunakan untuk berbagai kebutuhan rumah tangga, bisnis dan industri pendukung, dan perdagangan komersial. Peran energi dalam memenuhi kebutuhan rumah tangga, bisnis, dan industri, serta barang-barang yang diperdagangkan, mendorong penggunaannya dalam skala besar. Dengan demikian, meningkatnya kebutuhan komunitas energi membutuhkan pasokan energi yang tidak terbatas dan berlimpah. Namun, peningkatan kebutuhan masyarakat tidak diimbangi dengan pasokan sumber daya energi yang terbatas, karena telah dieksploitasi secara masif untuk memenuhi kebutuhan manusia.

Saat ini, negara-negara Asia Tenggara telah mengalami kesenjangan yang signifikan antara jumlah produksi energi dan konsumsi saat dibandingkan dengan tahun-tahun sebelumnya. Pemerintah negaranegara Asia Tenggara mempromosikan untuk mengembangkan sumber energi baru dan terbarukan karena wilayah tersebut kaya akan sumber energi yang berlimpah [59][60][61]. Saat ini, teknologi energi terbarukan telah dikenal secara luas sebagai alat untuk membatasi emisi gas rumah kaca dan memberikan solusi terintegrasi di sebagian besar negara [62][63]. Energi terbarukan dianggap sebagai energi yang ramah lingkungan, lebih bersih, ramah, dan lebih terjangkau [64][65][66]. Hal ini juga diduga dapat mendorong pertumbuhan ekonomi bangsa. Populasi yang terus meningkat, pertumbuhan ekonomi yang cepat dan sumber energi yang melimpah, mendorong adopsi energi terbarukan di negara-negara Asia Tenggara [67][68][69][70]. Beberapa negara di Asia Tenggara kini berupaya meningkatkan porsi sumber energi terbarukan untuk mengurangi ketergantungan pada bahan bakar fosil [71][72][73]. Kesenjangan yang lebih signifikan antara potensi pasokan dan permintaan energi dapat menghambat pembangunan ekonomi dan sosial di Asia Tenggara [74][75][16][76]. Energi terbarukan adalah sumber listrik yang tidak dapat dihindari untuk mengurangi emisi gas rumah kaca di wilayah tersebut [77][78][76][79].

Kebijakan untuk mempromosikan kepercayaan pada internet dan kegiatan digital sangat penting untuk meningkatkan partisipasi dalam ekonomi digital. Ini termasuk kebijakan dan peraturan tentang transaksi elektronik, arus data lintas batas, keamanan siber, privasi data, dan konsumen perlindungan. Sementara undang-undang tentang transaksi elektronik telah diberlakukan di sekitar kawasan Asia Tenggara, sebagian besar kebijakan dan peraturan data belum dikembangkan. Dalam beberapa kasus, mereka menimbulkan resiko potensial terhadap pertumbuhan ekonomi digital. Sebagai contoh, negaranegara yang mengadopsi kebijakan yang mengambil pendekatan menyeluruh yang membutuhkan pelokalan data didalam batas-batas nasional membatasi potensi perusahaan mereka sendiri untuk memanfaatkan teknologi digital sebagai kendaraan untuk pertumbuhan, dan resiko yang memicu pendekatan yang hampir sama terhadap kebijakan data di negara lain. Jika pemerintah mendefinisikan kebutuhan untuk melokalkan data, itu harus disyaratkan hanya dalam situasi yang terdefinisi dengan jelas, berdasarkan klasifikasi jenis dan penggunaan data, seperti nasional keamanan atau data kesehatan pribadi [80].

Kebijakan energi di Malaysia berfokus pada konservasi lingkungan, keberlanjutan, konsumsi sumber daya yang efektif, dan penyediaan layanan berkualitas tinggi bagi semua pemangku kepentingan [81]. Pembentukan kebijakan energi terbarukan di Malaysia telah melihat banyak upaya yang dilakukan oleh pemerintah untuk mengembangkan dan mempromosikan penggunaan sumber daya terbarukan, sementara juga terus mensubsidi harga produk minyak bumi terlepas dari kenaikan global harga mereka. Pada saat yang sama, program energi terbarukan skala kecil sedang dipromosikan. Sedangkan di Indonesia, konsumsi energi diperkirakan meningkat tiga kali lipat selama periode 2010-2030. Produksi energi tradisional dari bahan bakar fosil telah gagal mengimbangi perkembangan dan pertumbuhan. Untuk memastikan pasokan energi yang berkelanjutan, pemerintah memperkenalkan kebijakan untuk mengamankan energi untuk masa depan [82]. Salah satu faktor yang memiliki pengaruh besar pada dukungan energi non-fosil di Indonesia terkait dengan tata kelola multi-level. Kurangnya kesadaran akan niat nasional di antara otoritas daerah, bersama dengan konsultasi yang buruk dalam proses pembuatan kebijakan di antara para pembuat keputusan baik secara vertikal dan horizontal menyebabkan kesalahpahaman tentang keadaan lokal di antara para pembuat kebijakan nasional [83]. Faktor-faktor ini mewakili hambatan utama untuk pengembangan energi terbarukan. Ketika tata kelola multi-level mempromosikan energi terbarukan menjadi jauh lebih rumit tergantung pada sumber energi tertentu. Diferensiasi vertikal sejalan dengan proses pengambilan keputusan perlu ditambahkan pada fragmentasi tanggung jawab horisontal terkait regulasi energi [84] untuk memahami hambatan dan potensi dukungan energi terbarukan di Indonesia. 
Tabel 7. Kebijakan lanskap Asia Tenggara

\begin{tabular}{|c|c|}
\hline \\
\hline Negara & Kebijakan Lanskap \\
\hline Malaysia & $\begin{array}{c}\text { Target Energi Terbarukan, FiTs, RPS, kewajiban biofuel, insentif } \\
\text { fiskal, pembiayaan publik }\end{array}$ \\
\hline Indonesia & $\begin{array}{l}\text { Target Energi Terbarukan, FiTs, RPS, kewajiban biofuel, intensif } \\
\text { fiskal, pembiayaan publik, pelelangan umum }\end{array}$ \\
\hline Singapura & Pembiayaan publik, pelelangan umum, pengukuran bersih \\
\hline Thailand & $\begin{array}{c}\text { Target Energi Terbarukan, FiTs, kewajiban biofuel, insentif } \\
\text { fiskal, pembiayaan publik }\end{array}$ \\
\hline Filipina & $\begin{array}{l}\text { Target Energi Terbarukan, FiTs, RPS, kewajiban biofuel, insentif } \\
\text { fiskal, pembiayaan publik, pelelangan umum, pengukuran bersih }\end{array}$ \\
\hline Vietnam & $\begin{array}{c}\text { Target Energi Terbarukan, REC yang dapat diperdagangkan, } \\
\text { insentif fiskal }\end{array}$ \\
\hline Laos & N/A \\
\hline Kamboja & $\mathrm{N} / \mathrm{A}$ \\
\hline Brunei Darussalam & N/A \\
\hline Myanmar & N/A \\
\hline
\end{tabular}

Sumber: [9]

ASEAN diberkahi dengan sumber daya energi terbarukan yang berlimpah seperti energi angin, biomassa, tenaga air, panas bumi, energi surya dan lainnya. Meskipun memiliki potensi besar, pemanfaatannya saat ini relatif sedikit dibandingkan dengan sumber daya energi fosil dan mineral. Secara global, pengembangan energi angin adalah salah satu yang tercepat diantara sumber daya energi terbarukan. Kapasitas angin telah berlipat dua setiap 3 tahun sejak dekade terakhir sementara biaya teknologi telah menurun. Biaya saat ini adalah \$ 850-950 / kW untuk onshore dan \$1.100-1.200 / kW untuk lepas pantai [85]. Negara-negara ASEAN dengan rezim angin yang dapat dieksploitasi secara komersial adalah Kamboja, Indonesia, Laos, Filipina, Thailand, dan Vietnam. Pengukuran angin, studi proyek dan pengembangan secara aktif dilakukan di Filipina, Vietnam, dan Thailand. Meskipun potensi energi angin sangat besar, pemanfaatan sumber daya angin relatif kecil. ASEAN Pricing Standardization bertujuan untuk mempromosikan paritas harga perangkat lunak dan perangkat keras TI yang dijual kepada perusahaan di berbagai negara anggota ASEAN. Inisiatif Standardisasi Harga ASEAN selaras dengan tujuan Cetak Biru AEC 2025, untuk menciptakan 'Ekonomi Yang Sangat Terintegrasi dan Kohesif' dan 'A Global ASEAN'. Dengan mempromosikan paritas ASEAN dimulai dengan harga barang dan jasa, untuk memperkuat konsep identitas ASEAN yang harmonis di kancah internasional [86].

Menurut laporan IMF (2013) tentang subsidi energi, sebagian besar anggota ASEAN menyediakan energi subsidi. Laporan IMF juga menunjukkan bahwa dalam hal subsidi sebelum pajak, Indonesia memberikan subsidi tertinggi untuk produk minyak bumi (2,58 persen dari PDB) sementara Thailand memberikan subsidi tertinggi untuk listrik dan batubara (1,64 persen dan 0,25 persen dari PDB), masingmasing) dan Malaysia memberikan subsidi tertinggi untuk gas alam (0,31 persen dari PDB) [87]. Amandemen hukum nasional kemungkinan akan menjadi masalah rumit di antara anggota ASEAN; pada awalnya, ketika harmonisasi undang-undang sedang dikerjakan, potensi keuntungan dari perdagangan energi dan investasi masih harus dieksplorasi sambil mengakui batas-batas yang ditetapkan oleh hukum nasional. Berkenaan dengan reformasi peraturan untuk membantu liberalisasi perdagangan dan investasi, alternatifnya bisa dilanjutkan dengan tujuan bersama yaitu restrukturisasi pasar dan kompetisi yang dipimpin swasta atau untuk melanjutkan meskipun ada industri yang terintegrasi secara vertikal dan monopoli milik negara. Reformasi peraturan merupakan tantangan serius, mengingat beberapa anggota ASEAN bahkan tidak memiliki regulator independen (Tabel 8) [88].

Singapura pertama kali merilis panduan e-pajak tentang kerangka Pelaporan Negara demi Negara (CbCR) untuk perusahaan multinasional yang berkantor pusat di Singapura pada Oktober 2016. Indonesia merilis peraturan Menteri Keuangan PMK 213 pada Desember 2016, memberikan tenggat waktu yang sangat ketat bagi wajib pajak untuk mematuhi dengan peraturan baru tersebut. Malaysia dan Vietnam segera merilis pedoman mereka sendiri pada awal 2017. Kamboja memperkenalkan aturan TP pada Oktober 2017. Pada Januari 2018, Kabinet Thailand menyetujui Rancangan Undang-Undang penentuan harga transfer yang akan menambahkan ketentuan TP spesifik ke Kode Pendapatan, yang akan berlaku efektif untuk tahun-tahun akuntansi yang dimulai pada atau setelah 1 Januari 2017. Dengan beberapa perubahan legislatif diberlakukan pada Februari 2018, Singapura sekarang sepenuhnya berlangganan Tindakan 13 dan telah menerbitkan pedoman TP yang diperbarui, sepenuhnya mengadopsi Tindakan 8 hingga 10 tentang menyelaraskan hasil-hasil TP dengan penciptaan nilai [90]. 
Tabel 8. Situasi regulasi energi anggota ASEAN

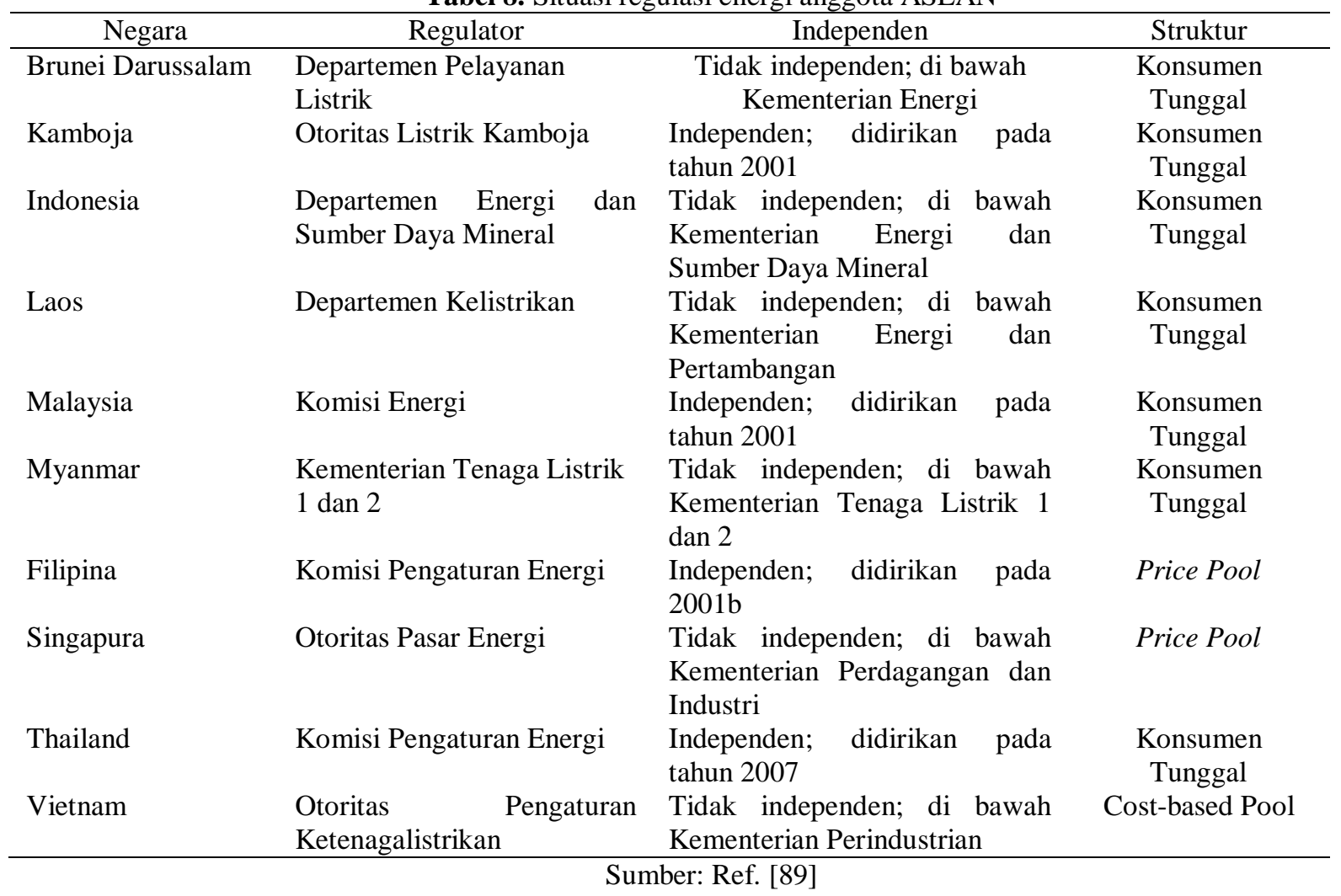

\section{Proyek Ekonomi}

Revolusi digital telah membawa banyak manfaat bagi Asia Tenggara, kawasan ini memiliki peluang unik untuk mencapai kemajuan yang lebih cepat dengan memperkuat fondasi ekonomi digitalnya yang terus tumbuh. Setiap sektor ekonomi di negara-negara ASEAN dapat berbuat lebih banyak untuk menggunakan teknologi digital dan model bisnis yang lebih cerdas. Untuk membantu sektor swasta, pemerintah juga perlu mengubah diri dalam menggunakan teknologi seperti analisis data dan sistem intelijen, mengembangkan platform digital, dan menyelaraskan pendekatan dengan prosedur pengaturan khusus untuk keamanan siber, identitas digital, dan manajemen data [91].

Salah satu cara bagi pemerintah untuk meningkatkan ekonomi adalah dengan memberikan peluang kepada investor dalam mengembangkan energi terbarukan [92][93]. Pemerintah negara-negara Asia Tenggara diharapkan dapat mengatasi masalah kekurangan energi dengan merumuskan kebijakan energi yang tepat. Akses ke energi terbarukan yang terlokalisasi dapat secara ekstensif meningkatkan kondisi ekonomi dengan cara memberdayakan masyarakat dan kelompok untuk mewujudkan kontrol atas pasokan energi, mengurangi harga energi, dan meningkatkan/menciptakan lapangan pekerjaan. Keuntungan finansial dari sumber listrik lokal yang berkelanjutan di daerah pedesaan, khususnya di antara orang miskin dan pulau-pulau terpencil di Asia Tenggara harus dinilai. Ada indikasi yang meningkat bahwa solusi energi terbarukan mengurangi penggunaan bahan bakar dan memfasilitasi penciptaan pendapatan dan penciptaan lapangan kerja, baik dalam rantai pasokan listrik terbarukan.

Sumber energi terbarukan terutama meliputi biomassa, teknologi limbah menjadi energi, angin, matahari, aliran sungai, sumber tenaga air yang menyumbat, lautan, sistem panas bumi dan hibrida. Lonjakan energi terbarukan saat ini sebagian besar disebabkan oleh penyebaran panel surya di Cina dan di seluruh dunia. Ini tumbuh 50 persen menjadi sekitar 74 gigawatt, menurut Badan Energi Internasional (IEA) [4]. Dengan perkiraan total permintaan energi mereka akan tumbuh hampir dua pertiga selama dua dekade berikutnya, sepuluh negara dari Perhimpunan Bangsa Bangsa Asia Tenggara (ASEAN) akan menjadi pengubah permainan yang signifikan bagi lanskap energi global. Wilayah ini diproyeksikan menjadi ekonomi terbesar keempat di dunia pada Tahun 2030. Populasi diperkirakan akan meningkat lebih dari 10\% menjadi 690 juta pada Tahun 2020. Energi sangat penting untuk pertumbuhan ekonomi seperti itu. Investasi dalam kapasitas pembangkit listrik dan infrastruktur akan diperlukan untuk memenuhi permintaan energi ASEAN, yang telah tumbuh sebesar $60 \%$ di masa lalu 15 tahun. Badan Energi Internasional (IEA) memperkirakan bahwa investasi akan berlanjut tumbuh dua pertiga lagi pada 
Tahun 2040 [85]. Studi ini berfokus pada kawasan ASEAN untuk mengembangkan pemahaman yang lebih baik tentang bagaimana dan untuk sejauh mana tiga pilar memperkuat perdagangan energi regional, memastikan investasi masuk pasokan energi terbarukan, dan meningkatkan efisiensi energi dapat membantu memperkuat energi keamanan di negara-negara berkembang ini.

ASEAN adalah pasar Internet dengan pertumbuhan tercepat di dunia. Dengan 125.000 pengguna baru masuk ke Internet setiap hari, ekonomi digital ASEAN diproyeksikan akan tumbuh secara signifikan, menambahkan sekitar \$ 1 triliun untuk PDB regional selama sepuluh tahun ke depan. Tetapi banyak hambatan besar menghalangi jalannya potensi ini. ASEAN telah menetapkan langkah-langkah kebijakan dan kerangka kerja penting, termasuk Cetak Biru AEC 2025, Masterplan tentang Konektivitas ASEAN 2025, dan Perjanjian Kerangka Kerja e-ASEAN, untuk mengatasi hambatan ini. Namun, tujuan ambisius ini akan menuntut penelitian terperinci, pembuatan kebijakan visioner, dan penerimaan substansial dari para pemangku kepentingan regional [6].

\section{Kesimpulan}

Energi terbarukan merupakan solusi pragmatis yang harus dikembangkan di kawasan ASEAN. Dimana Negara-negara ASEAN menghadapi sebuah tantangan terbesar untuk memenuhi kebutuhan dasar masyarakat ASEAN. Seiring dengan pertambahan jumlah populasi yang terus meningkat khususnya di daerah perkotaan (urban) menyebabkan permintaan energi yang juga meningkat. Namun dalam pemenuhan permintaan energi, Negara-negara ASEAN tetap harus memperhatikan pengembangan energi yang aman, terjangkau, dan berkelanjutan. Studi ini berfokus pada pengembangan pemahaman yang lebih baik tentang pengaruh tiga pilar dalam memperkuat perdagangan energi regional, memastikan investasi pasokan energi terbarukan, dan meningkatkan efisiensi energi yang dapat membantu dalam memperkuat energi keamanan di negara-negara berkembang.

\section{Referensi}

[1] Asia Pacific Review Trans-Asian pipe, "Building the TransAsean gas pipeline," Asia Pacific Review, 2003.

[2] R. Zissler, "Renewable Energy to Replace Coal Power in Southeast Asia October 2019 Pragmatism to Deliver a Sustainable Bright Future," 2019.

[3] S.M. Shafie, T.M.I. Mahlia, H.H. Masjuki, A. Andriyana, "Current energy usage and sustainable energy in Malaysia: a review Renew Sust Energ Rev," 15, pp. 4370-4377, 2015

[4] International Energy Agency (IEA), Southeast Asia Energy Outlook, 2019.

[5] ERIA, Energy diakses pada Tanggal 23 Februari 2020 di https://www.eria.org/research/topic/energy/?keyword=all\&sort=date-

desc\&start_rec $=0 \&$ page_size $=40$

[6] World Economic Forum. Can Southeast Asia keep up with growing energy demand? Diakses pada tanggal 23 Februari 2020 di https://www.weforum.org/agenda/2019/12/asean-southeast-asiaenergy-emissions-renewables/

[7] IRENA and ACE (ASEAN Centre for Energy), Renewable Energy Outlook for ASEAN: A REmap Analysis, Abu Dhabi and Jakarta, www.irena.org/. 2016.

[8] ASEAN RESP, "Renewable energy support programme for ASEAN", www.giz.de/en/ worldwide/16395.html. 2016.

[9] IRENA, Renewable Energy Market Analysis Southeast Asia, 2018

[10] S. W. Ang, W. L. Choong, T. S. Ng, "Energy Security: Definitions, Dimensions and Indexes. Renewable and Sustainable Energy Reviews," 42: 1077-1093, 2015.

[11] C. Winzer, "Conceptualizing Energy Security," Energy Policy, 46: 36-48, 2012.

[12] U. Aydin, D. Azhgaliyeva, "Assessing Energy Security in Caspian Region: The Geopolitical Implications to European Energy Strategy, In Achieving Energy Security in Asia: Diversification, Integration and Policy Implications, Farhad Taghizadeh-Hesary, Naoyuki Yoshino, Young Ho Chang and Aladdin Rillo (eds.) Singapore: World Scientific, p.257-290, 2019.

[13] D. Yergin, "Ensuring Energy Security," Foreign Affairs, 85(2): 69-82, 2006.

[14] G. E. Metcalf, "The Economics of Energy Security," In Annual Review of Resource Economics, Vol 6, edited by G. C. Rausser, 155-174. Palo Alto: Annual Reviews, 2014.

[15] B. K. Sovacool, I. Mukherjee, "Conceptualizing and Measuring Energy Security: A Synthesized Approach Energy," 36 (8): 5343-5355, 2011.

[16] S. Tongsopit, N. Kittner, Y. Chang, A. Aksornkij, W. Wangiiraniran, "Energy Security in ASEAN: A Quantitative Approach for Sustainable Energy Policy,” Energy Policy, 90: 60-72, 2016. 
[17] L. Yao, Y. Chang, "Energy Security in China: A Quantitative Analysis and Policy Implications," Energy Policy, 67: 595-604, 2014.

[18] The Asean Post, 30 December 2019, ASEAN growth slower than forecasted, Diakses pada Tanggal 16 Februari 2020 di https://theaseanpost.com/article/asean-growth-slower-forecasted

[19] OECD Developmnent Centre, Economic Outlook For Southeast Asia, China, and India 2019: Towards Smart Urban Transportation.

[20] OECD Development Centre, Medium-term Projection Framework (MPF-2019).

[21] Global-is-Asian Staff, ASEAN economic trends in 2018, Diakses pada https://lkyspp.nus.edu.sg/gia/article/asean-economic-trends-in-2018

[22] Asean. Asean Economic Integration Brief No. 05/June 2019

[23] Focus Economics, Economic Forecasts from the World's Leading Economist, Diakses pada 17 Februari 2020 di https://www.focus-economics.com/regions/asean

[24] Economic Outlook Report 2020, Southeast Asia Economic Overview, 2020.

[25] ASEAN UP. 4 ASEAN infographics: demography, top cities, urbanization. Diakses pada Tanggal 17 Februari 2020 di https://aseanup.com/asean-infographics-demography-top-cities-urbanization/

[26] Shawn Greene, ASEAN's Demographic Dividend. 2013 yang diakses pada Tanggal 16 February 2020 di https://www.aseanbriefing.com/news/asean-demographic-dividend/

[27] BMA - Bangkok Metropolitan Administration (2013) Statistical Profile of Bangkok 2013, Bangkok: Bangkok Metropolitan Administration.

[28] National Solar Observatory (NSO), Annual Report, 2011.

[29] Dapice, David, A. Jose, Gomez-Ibanez, N.X. Thanh, Ho Chi Minh City: The Challenges of Growth, Policy Dialogue Paper Number 2, Ho Chi Minh City: Harvard Kennedy School and United Nations Development Programme, 2010.

[30] UNPD - United Nations Population Division (2015) World Urbanization Prospects - The 2014 Revision, New York: United Nations.

[31] Demographia World Urban Areas, 13th Annual Edition, Belleville: Demographia, 2017.

[32] The World Bank, Annual Report, 2009.

[33] ASEAN Today, Kekuatan orang: urbanisasi secara radikal akan mengubah kota ASEAN oleh 2050. Diakses pada Tanggal 17 Februari 2020 di https://www.aseantoday.com/2019/11/the-power-ofpeople-urbanisation-will-radically-transform-asean-cities-by-2050/?lang=id

[34] K, Matus, K. M. Nam, N. E. Selin, L. N. Lamsal, J. M. Reilly, S. Paltsev, "Health Damages from Air Pollution in China," MIT Joint Program on the Science and Policy of Global Change," Report No. 196, 2011.

[35] HEI (Health Effects Institute) (2010), "Outdoor Air Pollution and Health in the Developing Countries of Asia: A Comprehensive Review," HEI International Scientific Oversight Committee, Special Report $18 . \quad$ Available at: http://ehs.sph.berkeley.edu/krsmith/publications/2011/heiasiareview.pdf.

[36] A.J. Cohen, H. R. Anderson, B. Ostra, K. D. Pandey, M. Kryzyanowski, N. Kunzli, K. Gutschmidt, A. Pope, I. Romieu, J. M. Samet, K. Smith, "The Global Burden of Disease Due to Outdoor Air Pollution," J. of Toxicology and Environmental Health Part A, 68, pp.1-7, 2005.

[37] CAI (Clean Air Initiative) (2010), Air Quality in Asia: Status and Trends 2010 Edition, Available at: http://cleanairinitiative.org/portal/sites/default/files/ documents/AQ_in_Asia.pdf.

[38] Greenpeace Southeast Asia, 2019, A haze-free ASEAN by 2020 - are we there yet? . diakses pada Tanggal 17 February 2020 di https://www.greenpeace.org/malaysia/press/2605/a-haze-free-aseanby-2020-are-we-there-yet/

[39] Kreft, Sönke, D. Eckstein, I. Melchior, 2016, "Global Climate Risk Index 2017: Who Suffers Most from Extreme Weather Events? Weather-related Loss Events in 2015 and 1996 to 2015," https:// germanwatch.org/de/download/16411.pdf, accessed June 8, 2017.

[40] Maplecroft, "Climate Vulnerability Index 2017," http://reliefweb.int/sites/reliefweb.int/files/resources/verisk\%20index.pdf, accessed February 22, 2020.

[41] NUPI, Impact of Climate Change on ASEAN International Affairs Risk and Opportunity Multiplier, ISSN: 1894-650X, 2017.

[42] Liu, Yang, Sheng, Zhong, Azhgaliyeva, Dina, Toward Energy Security in ASEAN: Impacts of Regional Integration, Renewables, and Energy Efficiency, 2019.

[43] International Energy Agency (IEA), Energy Security in ASEAN +6, 2019. 
[44] Sovacool, K. Benjamin, Energy Access and Energy Security in Asia and the Pacific, ISSN 1655$5252,2013$.

[45] ACE (2017), The 5th ASEAN Energy Outlook 2015-2040. ASEAN Centre for Energy, Jakarta. (http://www.aseanenergy.org/resources/the-5th-asean-energy-outlook/)

[46] IEEJ (2017), Asia/World Energy Outlook 2018, (https://eneken.ieej.or.jp/data/7748.pdf)

[47] APERC (2013), APEC Energy Demand and Supply Outlook, 5th Edition. Asia Pacific Energy Research Centre, Tokyo. (http://aperc.ieej.or.jp/publications/reports/outlook.php)

[48] Endang Jati Mat Sahid, T. C. Sin, G. C. Hock, "Energy Security in ASEAN Region: Its challenges. IOP Conf," Series: Earth and Environmental Science, 268, 012168, 2019.

[49] ASEAN Investment Report, Foreign Direct Investment and the Digital Economy in ASEAN, 2018.

[50] Master Plan on ASEAN Connectivity 2025, p.48.

[51] http://www.southeast-asia.atkearney.com/documents/10192/6986374/ASEAN+Digital+Revolution. pdf/86c51659-c7fb-4bc5-b6e1-22be3d801ad2

[52] https://sbr.com.sg/retail/news/chart-day-singapore-lags-japan-and-china-e-commerce-use

[53] https://www.mti.gov.sg/te-IN/Newsroom/Speeches/2018/11/Opening-remarks-for-the-ASEANAgreement-on-Electronic-Commerce

[54] https://www.bangkokpost.com/business/news/1586378/trade-department-pushes-12-priorities-forasean-chair

[55] https://www.rsis.edu.sg/rsis-publication/cms/co18003-aseans-electronics-sector-facing-thedisruptive-trends/\#.XD2IjPlubIU

[56] http://asw.asean.org/

[57] G. Faninger, Economic Perspectives of Renewable Energy Systems, pp. 1-119, 2012.

[58] E. Park, Potentiality of renewable resources: economic feasibility perspectives in South Korea, 2017.

[59] Y. Chang, Z. Fang, Y. Li, "Renewable energy policies in promoting financing and investment among the East Asia Summit countries: quantitative assessment and policy implications," Energy Policy 95, 427-436, 2016 https://doi.org/10.1016/j.enpol.2016.02.017

[60] L. Hu, X. Shi, S. Qiao, T. Lin, Y. Li, Y. Bai, B. Wu, S. Liu, N. Kornkanitnan, S. Khokiattiwong, "Sources and mass inventory of sedimentary polycyclic aromatic hydrocarbons in the Gulf of Thailand: implications for pathways and energy structure in SE. Asia. Sci. Total Environ. 575, 982-995, 2017. https://doi.org/ 10.1016/j.scitotenv.2016.09.158.

[61] S. Kumar, "Assessment of renewables for energy security and carbon mitigation in Southeast Asia: the case of Indonesia and Thailand," Appl. Energy, 163: 63-70, 2016. https://doi.org/10.1016/j.apenergy.2015.11.019.

[62] B. Geng, X. Zhang, Y. Liang, H. Bao, "Do favorable land price policy affect renewable energy industry? Evidence from photovoltaics, J. Clean. Prod. 119, 187-195, 2016. https:// doi.org/10.1016/j.jclepro.2015.08.062.

[63] K. Morita, K. Matsumoto, "Synergies among climate change and biodiversity conservation measures and policies in the forest sector: a case study of Southeast Asian countries," For. Policy Econ, 87, 59-69, 2018. https://doi.org/10.1016/j.forpol.2017.10.013.

[64] H. Hu, N. Xie, D. Fang, X. Zhang, "The role of renewable energy consumption and commercial services trade in carbon dioxide reduction: evidence from 25 developing countries," Appl. Energy, 211, 1229-1244, 2018. https://doi.org/10.1016/j. apenergy.2017.12.019.

[65] B. Kahouli, "The causality link between energy electricity consumption, $\mathrm{CO} 2$ emissions, R\&D stocks and economic growth in Mediterranean countries (MCs)," Energy 145, 388-399, 2018. https://doi.org/10.1016/j.energy.2017.12.136.

[66] S. Nasreen, S. Anwar, I. Ozturk, "Financial stability, energy consumption and environmental quality: evidence from South Asian economies," Renew. Sust. Energ. Rev. 67, 1105-1122, 2017. https://doi.org/10.1016/j.rser.2016.09.021.

[67] E. Biyik, M. Araz, A. Hepbasli, M. Shahrestani, R. Yao, L. Shao, E. Essah, A.C. Oliveira, T. del Caño, E. Rico, J.L. Lechón, L. Andrade, A. Mendes, Y.B. Atlı, "A key review of building integrated photovoltaic (BIPV) systems," Eng. Sci. Technol. an Int. J. 20, 833-858, 2017. https://doi.org/10.1016/j.jestch.2017.01.009

[68] N. Jakica, "State-of-the-art review of solar design tools and methods for assessing daylighting and solar potential for building-integrated photovoltaics," Renew. Sust. Energ. Rev. 81, 1296-1328, 2018. https://doi.org/10.1016/j.rser.2017.05.080. 
[69] F. Obeidat, "A comprehensive review of future photovoltaic systems," Sol. Energy 163, 545-551, 2018. https://doi.org/10.1016/j.solener.2018.01.050.

[70] A. K. Shukla, K. Sudhakar, P. Baredar, "A comprehensive review on design of building integrated photovoltaic system. Energy Build," 128: pp. 99-110, 2016. https://doi.org/ 10.1016/j.enbuild.2016.06.077.

[71] Y. B. Assoa, L. Gaillard, C. Ménézo, N. Negri, F. Sauzedde, "Dynamic prediction of a building integrated photovoltaic system thermal behaviour," Appl. Energy, 214, 73-82, 2018. https://doi.org/10.1016/j.apenergy.2018.01.078

[72] N. Gupta, A. Tiwari, G.N. Tiwari, "Exergy analysis of building integrated semitransparent photovoltaic thermal (BiSPVT) system. Eng. Sci. Technol," an Int. J., 20, 41-50, 2017. https://doi.org/10.1016/j.jestch.2016.09.013.

[73] M. Tripathy, H. Joshi, S. K. Panda, "Energy payback time and life-cycle cost analysis of building integrated photovoltaic thermal system influenced by adverse effect of shadow. Appl. Energy 208, 376-389, 2017. https://doi.org/10.1016/j.apenergy.2017.10.025

[74] T. Ahmed, S. Mekhilef, R. Shah, N. Mithulananthan, M. Seyedmahmoudian, B. Horan, "ASEAN power grid: a secure transmission infrastructure for clean and sustainable energy for South-East Asia," Renew. Sust. Energ. Rev. 67, 1420-1435, 2017, https://doi. org/10.1016/j.rser.2016.09.055

[75] P. H. Shaikh, N. B. M. Nor, A. A. Sahito, P. Nallagownden, I. Elamvazuthi, M. S. "Shaikh, Building energy for sustainable development in Malaysia: a review," Renew. Sust. Energ. Rev. 75, 1392-1403, 2017. https://doi.org/10.1016/j.rser.2016.11.128.

[76] N. Wang, P. E. Phelan, C. Harris, J. Langevin, B. Nelson, K. Sawyer, "Past visions, current trends, and future context: a review of building energy, carbon, and sustainability," Renew. Sust. Energ. Rev. 82, 976-993, 2018. https://doi.org/10.1016/j.rser.2017.04.114.

[77] S. A. Sarkodie, V. Strezov, "Assessment of contribution of Australia's energy production to CO2 emissions and environmental degradation using statistical dynamic approach. Sci," Total Environ, 639, 888-899, 2018. https://doi.org/10.1016/j. scitotenv.2018.05.204.

[78] S. T. Tan, H. Hashim, P.Y. Hoo, A. H. A Rashid, J. S. Lim, W. S. Ho, "Mitigation the transboundary haze in ASEAN country: biomass to energy GHG emission assessment," Energy Procedia 105, 1178-1183, 2017. https://doi.org/10.1016/j.egypro.2017.03.406

[79] H. Zhu, L. Duan, Y. Guo, K. Yu, "The effects of FDI, economic growth and energy consumption on carbon emissions in ASEAN-5: evidence from panel quantile regression," Econ. Model, 58, 237-248, 2016. https://doi.org/10.1016/j.econmod.2016.05.003.

[80] ASEAN, Investing in ASEAN 2019/2020, 2019.

[81] T.H. Oh, M. Hasanuzzaman, J. Selvaraj, S.C. Teo, S.C. Chua, "Energy policy and alternative energy in Malaysia: issues and challenges for sustainable growth - an update Renew Sust Energ Rev," 81 (2018), pp. 3021-3031.

[82] S. Mujiyanto, G. TiessSecure energy supply in 2025: Indonesia's need for an energy policy strategy Energy Policy, 61 (2013), pp. 31-41

[83] F.W. Geels The multi-level perspective on sustainability transitions: responses to seven criticisms Environ Innov Soc Transit, 1 (2011), pp. 24-40

[84] J. Marquardt, "How power affects policy implementation: lessons from the Philippines," J Curr Southeast Asian Aff, 36 (2017), pp. 3-27.

[85] IEA, The Electricity Act 2003, 2017.

[86] ACIOA. ASEAN Pricing Standardization. Diakses pada Tanggal 23 February 2020 di https://acioa.com/asean-pricing-standardization/

[87] IMF, 2013. "Energy subsidy reform: Lessons and implications". International Monetary Fund, Washington, D.C.

[88] Navarro, M. Adoracion, Sambodo, M. Tri, Working Paper The Pathway to ASEAN Energy Market Integration PIDS Discussion Paper Series, No. 2013-49, 2013.

[89] P. Ruangrong, 2013, "Overview of recent regulatory developments", presentation to the HighLevel Meeting of Regional Energy Regulatory Associations of Emerging Markets. Available at http://www.erranet.org/OtherActivities/high-level_meetings (accessed 10 July 2013].

[90] L. Coronado, EY, 2018, Transfer Pricing Updates: A Southeast Asia Perspective. Diakses pada Tanggal 23 February 2020 di https://www.expertguides.com/articles/transfer-pricing-updates-asoutheast-asia-perspective/ARRXILLY

[91] The world Bank, With the Right Policies and Investment, Southeast Asia can Take its Digital Economy to the Next Level. Diakses pada Tanggal 24 February 2020 di 
https://www.worldbank.org/en/news/press-release/2019/06/05/with-the-right-policies-andinvestment-southeast-asia-can-take-its-digital-economy-to-the-next-level

[92] C. A. Gabriel, J. Kirkwood, 2016, Business models for model businesses: lessons from renewable energy entrepreneurs in developing countries. Energy Policy 95, 336-349. https://doi.org/10.1016/j.enpol.2016.05.006.

[93] S. Sen, S. Ganguly, 2017, Opportunities, barriers and issues with renewable energy development a discussion. Renew. Sust. Energ. Rev. 69, 1170-1181. https://doi.org/ 10.1016/j.rser.2016.09.137. 